\title{
The role of connexin proteins and their channels in radiation-induced atherosclerosis
}

\author{
Raghda Ramadan $^{1,2} \cdot$ Sarah Baatout ${ }^{1,3} \cdot$ An Aerts $^{1} \cdot$ Luc Leybaert $^{2}(\mathbb{C}$
}

Received: 16 July 2020 / Revised: 29 October 2020 / Accepted: 17 November 2020 / Published online: 3 January 2021

(c) The Author(s) 2021

\begin{abstract}
Radiotherapy is an effective treatment for breast cancer and other thoracic tumors. However, while high-energy radiotherapy treatment successfully kills cancer cells, radiation exposure of the heart and large arteries cannot always be avoided, resulting in secondary cardiovascular disease in cancer survivors. Radiation-induced changes in the cardiac vasculature may thereby lead to coronary artery atherosclerosis, which is a major cardiovascular complication nowadays in thoracic radiotherapytreated patients. The underlying biological and molecular mechanisms of radiation-induced atherosclerosis are complex and still not fully understood, resulting in potentially improper radiation protection. Ionizing radiation (IR) exposure may damage the vascular endothelium by inducing DNA damage, oxidative stress, premature cellular senescence, cell death and inflammation, which act to promote the atherosclerotic process. Intercellular communication mediated by connexin $(\mathrm{Cx})$-based gap junctions and hemichannels may modulate IR-induced responses and thereby the atherosclerotic process. However, the role of endothelial Cxs and their channels in atherosclerotic development after IR exposure is still poorly defined. A better understanding of the underlying biological pathways involved in secondary cardiovascular toxicity after radiotherapy would facilitate the development of effective strategies that prevent or mitigate these adverse effects. Here, we review the possible roles of intercellular $\mathrm{Cx}$ driven signaling and communication in radiation-induced atherosclerosis.
\end{abstract}

Keywords Ionizing radiation - Atherosclerosis $\cdot$ Intercellular communication $\cdot$ Bystander effect $\cdot$ Connexin $\cdot$ Gap junction $\cdot$ Hemichannels

$\begin{array}{ll}\text { Abbreviations } \\ \text { ATP } & \text { Adenosine triphosphate } \\ \text { Cx } & \text { Connexion } \\ \text { CVD } & \text { Cardiovascular diseases } \\ \text { CL } & \text { Cytoplasmic loop } \\ \text { CT } & \text { C-terminal tail } \\ \text { COX-2 } & \text { Cyclooxygenase-2 } \\ \text { DNA } & \text { Deoxyribonucleic acid } \\ \text { DSB } & \text { Double-strand breaks } \\ \text { eNOS } & \text { Endothelial nitric oxide synthase } \\ \text { EL } & \text { Extracellular loop } \\ \text { Gy } & \text { Gray }\end{array}$

Luc Leybaert

Luc.Leybaert@UGent.be

1 Radiobiology Unit, Belgian Nuclear Research Centre (SCK CEN), Mol, Belgium

2 Department of Basic and Applied Medical Sciences, Physiology group, Ghent University, Ghent, Belgium

3 Department of Molecular Biotechnology, Ghent University, Ghent, Belgium

$\begin{array}{ll}\text { IR } & \text { Ionizing radiation } \\ \text { IP3 } & \text { Inositol triphosphate } \\ \text { IL } & \text { Interleukin } \\ \text { JNK } & \text { C-jun N-terminal kinase } \\ \text { kDa } & \text { Kilo-Dalton } \\ \text { LDL } & \text { Low-density lipoprotein } \\ \text { MAPK } & \text { Mitogen-activated protein kinase } \\ \text { MCP-1 } & \text { Monocyte chemotactic protein-1 } \\ \text { NF- } \text { B } & \text { Nuclear factor kappa-light-chain-enhancer of } \\ & \text { activated B cells } \\ \text { NO } & \text { Nitric oxide } \\ \text { NT } & \text { NH } 2 \text { termini } \\ \text { RIBE } & \text { Radiation-induced bystander effect } \\ \text { ROS } & \text { Reactive oxygen species } \\ \text { RNS } & \text { Reactive nitrogen species } \\ \text { SSB } & \text { Single-strand break } \\ \text { TGF } & \text { Transforming growth factor } \\ \text { TNF } & \text { Tumor necrosis factor } \\ \text { TM } & \text { Transmembrane domain } \\ \text { VCAM-1 } & \text { Vascular cell adhesion molecule 1 }\end{array}$




\section{Introduction}

Cardiovascular disease (CVD) is the leading cause of morbidity and mortality worldwide, with $31 \%$ of all global deaths in 2016, according to the World Health Organization (WHO). The most common causes of CVD morbidity and mortality are myocardial infarction, stroke, coronary artery disease, and congestive heart failure [1]. Atherosclerosis is considered the major underlying cause of CVD development [2]. The progression of atherosclerosis and the risk of CVD are influenced by the presence of a combination of risk factors, such as dietary factors, tobacco use, physical inactivity, hypertension, age, gender, hyperlipidemia, and genetic predisposition [3]. Growing evidence indicates that exposure to ionizing radiation (IR) is also associated with an increased risk of CVD [4-12].

The medical use of IR plays a key role in cancer treatment with about $50 \%$ of cancer patients receiving radiotherapy for curative and/or supportive therapy during the course of their treatment [13]. Incidental IR exposure to the heart and large arteries occurs during radiotherapy for thoracic malignancies such as breast cancer, head and neck cancer, Hodgkin's lymphoma, and esophageal cancer [14]. Large-scale epidemiological studies have established a link between high and medium doses of IR exposure ( $>0.5 \mathrm{~Gy}$ ) and the risk for CVD [5, 9, 11, 15-17]. In addition, meta-analyses of epidemiological studies, and other experimental studies suggest that even low radiation doses $(<0.5 \mathrm{~Gy})$ can generate cardiovascular morbidity [7, 9, 18-23].

Radiation treatment is known to cause cellular effects such as oxidative stress, DNA damage, cellular $\mathrm{Ca}^{2+}$ overload, apoptosis, premature cell senescence and promotes inflammation which may induce vascular endothelium damage, an early marker for atherosclerosis [24-30] (reviewed in $[31,32])$. Cellular and molecular changes induced by radiation exposure occur not only in directly irradiated cells, but also in neighboring non-irradiated cells, a process known as the 'radiation-induced bystander effect' (RIBE) [33, 34]. Transmembrane connexin $(\mathrm{Cx})$ proteins are critical modulators of this process by forming gap junction channels that provide intercellular communication routes between neighboring cells, and hemichannels, that mediate paracrine communication pathway. While understanding of the molecular mechanisms of IR-induced atherosclerosis has increased, the role of intercellular communication, particularly the role of endothelial Cxs and their channels, in the development of radiation-induced atherosclerosis is still poorly defined. Here, we review the role of intercellular communication in radiation-induced atherosclerosis, with the focus on radiation-induced bystander response and a possible role of Cxs in radiation-induced atherosclerosis.

\section{Intercellular communication in atherosclerosis development and the response to ionizing radiation exposure}

\section{Radiation-induced bystander effect (RIBE)}

Biological responses in non-irradiated cells are defined as non-targeted effects [35], which may include genomic instability, bystander effects, and abscopal effects [35-37]. Radiation-induced genomic instability can be observed as a delayed and stochastic appearance of de novo gene mutations, chromosomal aberrations, and reproductive cell death in the progeny of irradiated cells [38]. Bystander effect pertains to cells adjacent to irradiated cells, while the abscopal effect may reach further tissues outside of the irradiated volume, and it relies more on clinical observations in patients receiving radiotherapy $[35,39]$.

\section{RIBE: experimental data}

In vitro studies Traditionally, it was accepted that exposure to IR only affected directly irradiated cells. However, in 1992, Nagasawa et al. reported that irradiating $1 \%$ of Chinese hamster ovary cells with $\alpha$-particles led to genetic damage in more than $30 \%$ of cells [40]. This observation was later confirmed by others in human fibroblast cells [41]. This means that non-irradiated cells exhibit effects as a result of signals received from adjacent irradiated cells, a process known as radiation-induced bystander effect (RIBE) [34, 42]. Since then, RIBE has been observed in several in vitro studies for different biological endpoints such as cell death, apoptosis, senescence, DNA damage, gene mutations, chromosomal aberrations, genomic instability, cell differentiation, cell cycle distribution, and gene expression (reviewed in [43, 44], and [45]). Bystander effects have mainly been studied in vitro using various techniques (medium transfer, co-culture method and microbeam irradiation which provided clear evidence of RIBE) [43, 46, 47], distinct cell types (normal and cancerous cells) [41, 48, 49], and different culture systems (two and three-dimensional models) $[49,50]$. RIBE has been reported to be induced both by high-LET irradiation [47, 51-53], as well as low-LET irradiation after high doses ( $>2$ Gy) [54-56], medium and low doses of exposure (>2 Gy) [57-59], utilizing a variety of dose rates [60]. These studies showed that RIBE depends on radiation quality, radiation dose, and dose rate used. RIBE was also reported in response to fractionated irradiation exposure commonly used in radiotherapy, which appears to be dependent on cell type, dose/dose rate, and the interval between fractions [61, 62]. 
High- and low-LET radiation experimental in vitro evidence overall indicates that the classic bystander effect is detrimental for the cells [38, 51, 63-65]. However, nonclassic bystander effects have also been described, reporting increased survival of bystander cells after high dose irradiation [66]. Moreover, the so-called radiation-induced adaptive response, which is the acquisition of radiation resistance induced by priming the cells with low dose irradiation [66, 67] [68, 69], will also act to dampen the bystander effect.

In the context of radiation-induced atherosclerosis, an in vitro study was performed to investigate the crosstalk between irradiated macrophages and human umbilical vein endothelial cells. In this study, $3 \mathrm{~Gy} \gamma$-irradiated macrophage cells were reported to trigger apoptosis and inflammatory responses in bystander endothelial cells via a p38-dependent pathway [70]. This involved VCAM-1, a pro-inflammatory molecule that enhances monocyte-endothelial adhesion and is a key event in initiating atherosclerosis [71], and MMP-9 that plays an important role in endothelial dysfunction by triggering apoptosis and inflammation [70, 72].

Animal studies Next to the extensive set of in vitro bystander studies, several in vivo animal studies reported RIBE using distinct radiation qualities, radiation doses and dose rates, where oxidative stress, apoptosis, DNA damage, and genetic/epigenetic dysregulations were observed in bystander-shielded organs such as spleen and lung [44, 73-76]. These studies indicated that oxidative stress plays an important role in RIBE in vivo since (pre)treatment of animals with antioxidants significantly reduced DNA damage in shielded regions $[75,76]$. Moreover, bystander effects in animals were shown to follow a distinct time scale with consequences persisting for several months after radiation exposure [77]. Camphausen et al. suggested that in vivo bystander responses may result in an anti-tumor effect. They observed that fractionated $\gamma$-irradiation of mouse legs, $5 \times 10$ Gy fractions, and $12 \times 2$ Gy fractions, slowed down tumor growth in the midline dorsum in a dose-dependent manner, an effect that was mediated by p53 [78]. Mancuso et al. provided proof-of-principle and mechanistic evidence for RIBE involvement in vivo [79, 80]. They reported tumor induction in bystander-shielded cerebellum of Patched homolog-1 heterozygous radiosensitive mice after X-ray exposure of the lower part of the body. It was furthermore demonstrated that gap junction intercellular communication, together with ATP release and connexin 43 upregulation, were involved in transmission of oncogenic bystander signals to the central nervous system.

In humans Clinically, it is well known that local radiotherapy for different types of cancer may induce distant effects known as "abscopal effects" [42, 81, 82]. The first study (1954) that suggested non-targeted abscopal effects, reported a decrease in the bone marrow cellularity of children that received $\mathrm{X}$-irradiation to their spleen for chronic granulocytic leukemia treatment [83]. Since then, several studies reported abscopal effects in cases where radiotherapy was combined with immune checkpoint inhibitors or immunotherapeutic agents that enhance the immune response in general [84-86]. Abscopal effects may in principle be clinically useful to extend the radiation effects to tumor cells outside the radiation field [81] but they may as well be harmful when reaching distant healthy cells and tissues [5], effectively restricting their application.

The occurrence of secondary cancers in patients treated with radiotherapy, e.g. the development of lung, sarcoma and melanoma cancers after prostate cancer radiotherapy $[87,88]$, is well established. Another example is the high incidence of secondary lung cancer in ovarian, rectal, and cervical cancer patients treated with radiotherapy $[89,90]$. In addition, as previously stated, several studies have reported an increased risk for non-cancerous diseases such as CVD in radiotherapy-treated patients [18]. Due to individualized dose calculation advancements and the prescribed targeted technical approaches in radiotherapy, it is speculated that scattered radiation cannot be the sole trigger explaining the high incidence of secondary cancer as well as non-cancer side effects after radiotherapy. RIBE is postulated to play a role in the development of these post-radiotherapy side effects [91, 92].

\section{RIBE: underlying molecular mechanisms and the possible link to atherosclerosis}

Although RIBE has improved our understanding of the nontargeted effects after radiotherapy, its molecular mechanisms are complex and not fully understood. Two main routes were reported to underly bystander signals: (i) direct cell-to-cell communication, often mediated by gap junctions and (ii) paracrine release of soluble messengers/factors from directly irradiated cells to the extracellular environment [93, 94]. Paracrine release can be mediated by vesicular release mechanisms in general, exosome release in particular, and by the opening of large pore channels such as connexin hemichannels $[95,96]$. Given the prominent role of ATP release in bystander signaling, paracrine purinergic communication through P2X and P2Y receptor families may take a central stage [97-99].

The bystander effect induced by IR involves diverse signaling molecules. Oxidative stress molecules, including reactive oxygen and nitrogen species are the main culprits in activating DNA damage and apoptosis in bystander cells [100, 101]. Oxidative stress also plays a crucial role in the pathophysiology of atherosclerosis, since it is associated with activation of inflammatory and apoptotic pathways that contribute to endothelial cell injury (Fig. 1) [102, 103]. 
Fig.1 Molecular mechanisms responsible for radiationinduced endothelial cell damage and the development of atherosclerosis

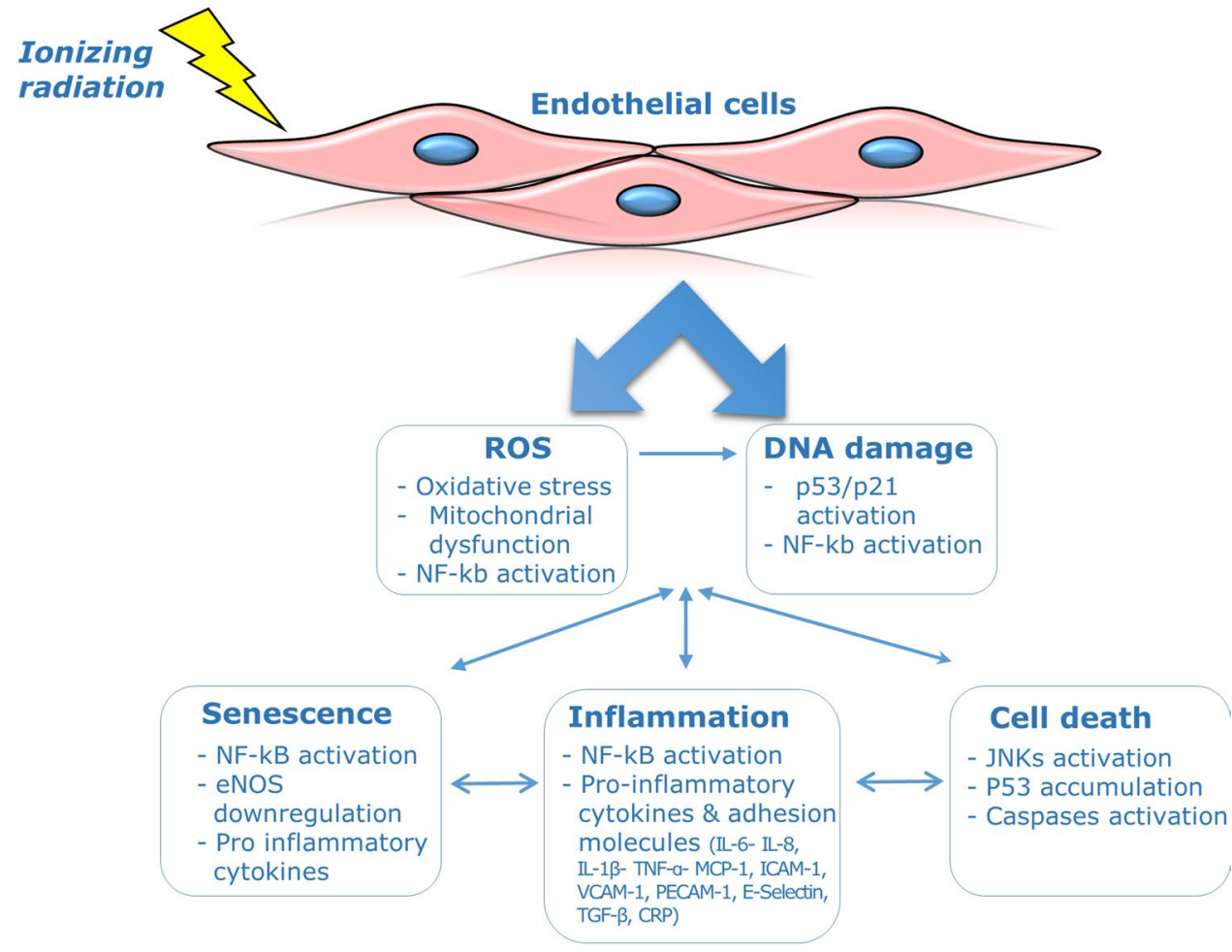

Endothelial cell dysfunction

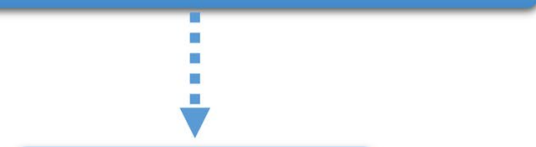

Atherosclerosis

In addition to oxidative stress, IR also triggers the release of various cytokines (e.g. TNF- $\alpha$, TGF- $\beta$, IL-1, IL-2, IL-6, and IL-8) largely - but not exclusively-derived from nonirradiated lymphocytes and macrophages [33, 34, 104, 105]. It is well recognized that atherosclerosis is a chronic inflammatory disease, and elevation of these cytokines in non-irradiated bystander cells may impact the time course of atherosclerotic alterations (Fig. 1) [71]. Therefore, irradiated cancer cells as well as endothelial cells during thoracic radiotherapy, may induce oxidative stress and inflammation in non-irradiated endothelial cells in the cardiovascular system and lead to endothelial injury, which may set the path for atherosclerotic development.

Besides ROS and inflammation, there is substantial evidence that $\mathrm{NF}_{-\mathrm{k}} \mathrm{b}$ and MAPK signaling pathways, as well as signaling by intracellular calcium ions $\left(\mathrm{Ca}^{2+}\right)$, cyclooxygenase-2 (COX-2), extracellular ATP, nitric oxide (NO) and $\mathrm{p} 53$ protein are involved in bystander effects in nontargeted cells after radiation exposure [33, 63, 106-110]. Epigenetic modulation was also reported to play a role in bystander responses, since changes in DNA methylation and in miRNAs expression have been observed in non-irradiated tissues [77, 111, 112]. In addition, cellular senescence has been proposed to contribute to RIBE, since senescent cells express a particular senescence-associated secretory phenotype that, together with ROS, may activate $\mathrm{NF}_{\mathrm{k}} \mathrm{b}$ leading to a DNA damage response, mitochondrial dysfunction, and inflammation in bystander cells [113-115]. RIBE can also be mediated by the cysteine protease cathepsin B, based on observations in $C$. Elegans, which is regulated by a p53 homologue and acts through insulin-like growth factor receptor signaling resulting in inhibition of cell death and increased embryonic lethality [116].

Several in vitro and in vivo studies have indicated a role for $\mathrm{p} 53$ protein, $\mathrm{NF}_{\mathrm{k}} \mathrm{b}$, and MAPK signaling cascades in the pathogenesis of atherosclerosis (Fig. 1). It was reported that activation of MAPK and $\mathrm{NF}_{-} \mathrm{b}$ signaling mediates crucial mechanisms involved in the pathogenesis of atherosclerosis such as endothelial cell activation, inflammation, intimal smooth muscle cell proliferation, and T-lymphocyte differentiation [117-121]. It was also reported that foam cell formation in the atherosclerotic lesion depends on JNK2 
and $\mathrm{p} 38 \alpha$ MAPK activation [122, 123]. Additionally, it was observed that endothelial-specific $\mathrm{NF}_{-\mathrm{k}} \mathrm{b}$ inhibition protected mice from atherosclerosis development by reducing the expression of vascular adhesion molecules, cytokines and chemokines and preventing macrophage recruitment to atherosclerotic plaques, hence strongly reducing atherosclerotic plaque formation [121]. Activation of p53, in response to oxidative stress and DNA damage, was also reported to induce apoptosis and premature senescence in vascular endothelial and smooth muscle cells [124, 125]. Moreover, activation of the NF- $\mathrm{kb}$ pathway and sustained inflammation has been illustrated in irradiated arteries of patients that were treated with radiotherapy [126].

As such, a possible explanation of the cardiovascular effects after thoracic radiotherapy is through the radiation doses received in the heart region, which is estimated to be in the order of 1-20 Gy [5, 18, 127-131]. These doses may damage the endothelium directly to initiate the atherosclerosis process, which may expand via bystander signaling to non-irradiated endothelial cells [55] (Fig. 2).

Irradiated cancer or endothelial cells during thoracic radiotherapy may produce bystander responses to non-irradiated endothelial cells in the cardiovascular system via three main routes: (i) by direct cell-to-cell communication via $\mathrm{Cx}$-based gap junctions, (ii) by paracrine release of soluble factors (e.g. ATP, released via vesicular mechanisms or Cx hemichannels) to the extracellular environment and (iii) by exosomes, which may use Cxs to interact with their targets [132]. Not all the cells are affected by bystander signaling (fade pink cell). Macrophages may be important mediators in the bystander response, by regulating cytokine release to bystander cells. Reactive oxygen and nitrogen species (ROS/
RNS), signaling cyclooxygenase-2 (COX-2) together with signal transduction through p53, MAPKs and NF-kb may be involved in bystander responses in non-targeted endothelial cells after radiation exposure. Eventually, these signaling molecules may participate in endothelial cell dysfunction by triggering DNA damage, apoptosis, senescence, mitochondrial dysfunction and inflammation.

\section{Intercellular communication and the role of connexins in atherosclerosis}

\section{Connexins and their channels}

As delineated before, gap junctions and hemichannels play an important role in communicating bystander signals. Both gap junctions and hemichannels are composed of a transmembrane protein called connexin (Cx) (Fig. 3). There are 21 human $\mathrm{Cx}$ isoforms (20 in the murine genome), which exist in either phosphorylated or non-phosphorylated forms. The nomenclature of $\mathrm{Cx}$ is based on their molecular weight, which ranges from 25 to $62 \mathrm{kDa}$ [34]. Each $\mathrm{Cx}$ protein consists of four transmembrane domains (TM1-4). These domains are connected by two extracellular loops (EL) that regulate docking processes and cell-cell recognition. The proteins have a cytoplasmic carboxy-terminal tail (CT), amino-terminal tail (NT), and a short cytoplasmic loop (CL) linking TM2 and TM3. Six Cx proteins oligomerize to form a hemichannel; two opposed hemichannels from adjacent cells form a gap junction channel by the interaction of conserved domains on the extracellular loops of hemichannels [133]. The life cycle of Cxs is characterized by various steps, including $\mathrm{Cx}$ trafficking to the cell surface,

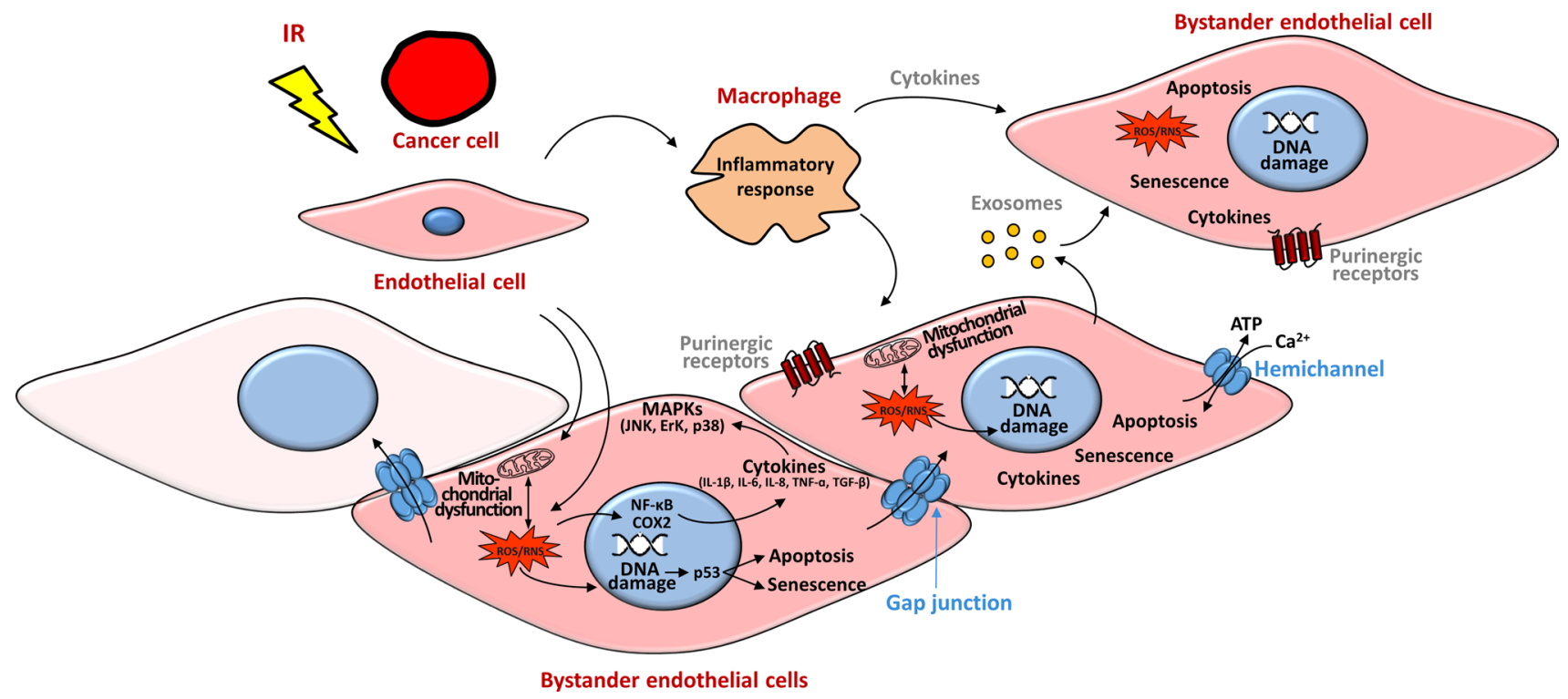

Fig. 2 Pathways of radiation-induced signaling potentially leading to bystander endothelial dysfunction 
Fig. 3 Molecular architecture of Cxs, hemichannels, and gap junctions. Cx proteins consist of four TMs, two ELs, one CL and a cytoplasmic NT and CT. Gap junctions are composed of $12 \mathrm{Cx}$ proteins, organized as two hexameric hemichannels of two apposed cells. $C x$ connexin, $T M$ transmembrane domain, $E L$ extracellular loop, $C L$ cytoplasmic loop, $N T \mathrm{NH}_{2}$ terminus, $C T$ $\mathrm{COOH}$ terminus [133]

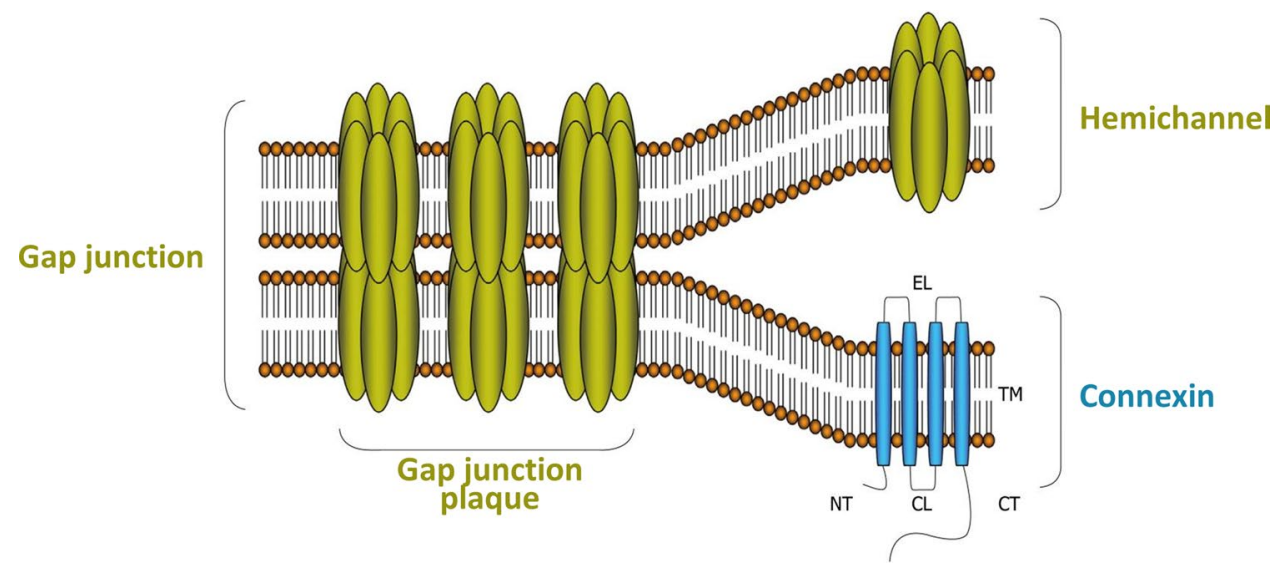

hemichannel formation, gap junction assembly, gap junction plaque formation, and closure of the cycle by gap junction disassembly through internalization and degradation (Fig. 3) [134]. Cxs are expressed in a tissue- and cell-specific manner, with $\mathrm{Cx} 43$ being the most abundant and widespread isotype in mammals. $\mathrm{Cx} 43$ is also a major isotype in the cardiovascular system and is especially abundant in ventricular cardiomyocytes [135, 136]. Apart from the cardiovascular system, $\mathrm{Cx} 43$ has also major functions in brain astrocytes and vascular endothelial cells, the kidneys and the reproductive organs [137].

The physiological role of Cxs has been demonstrated by gene knockout studies and human diseases associated with $\mathrm{Cx}$ mutations. For instance, $\mathrm{Cx} 43$-knockout mice die at birth due to cardiac malformation, illustrating the crucial role of this specific isotype in development [138]. Moreover, $\mathrm{Cx} 43$ deletion in mice has a major impact on the gene network and dysregulates genes involved in the differentiation and function of vascular cells and in vasculogenetic/angiogenetic signaling pathways, therefore interfering with normal development of coronary arteries $[139,140]$. The deletion of one allele of $\mathrm{Cx} 43$ in $\mathrm{Cx} 40$-knockout mice exhibited cardiac malformations and led to neonatal death [141]. The simultaneous ablation of $\mathrm{Cx} 37$ and $\mathrm{Cx} 40$ caused vascular abnormalities in intestine, skin, stomach, lung, and testis [142]. Polymorphisms of Cx37 were reported to be associated with coronary artery disease, including atherosclerosis, and myocardial infarction [143-145]. These observations highlight the role of Cxs in the development of the vasculature and for maintaining vascular homeostasis.

Next to the physiological role of $\mathrm{Cx}$ proteins, cell-cell communication via gap junctions and hemichannels may become disturbed as cause or consequence under pathological conditions [34]. Gap junctions permit passive diffusion of atomic ions (e.g. $\mathrm{Ca}^{2+}, \mathrm{Na}^{+}, \mathrm{Cl}^{-}$and $\mathrm{K}^{+}$) and of small (molecular weight below $\sim 1.5 \mathrm{kDa}$ ) hydrophilic molecules (e.g. ATP, glucose, glutamate, IP3 and glucose) and other second messenger molecules between adjacent cells [146].
Gap junctions are usually open to promote crosstalk between the cells and to facilitate the propagation of chemical and electrical signals between the cytoplasm of neighboring cells, thereby serving as a key mechanism in the synchronization of physiological signals [146-148]. In the heart, gap junction channels facilitate action potential conduction along conductive tissues as well as between cardiomyocytes, and synchronize the atrioventricular contraction cycle [148, 149]. In the vascular wall, gap junctions in endothelial cells, smooth muscle cells and between these cells facilitate electrical and chemical signaling, thereby coordinating vasoactive responses [148-150].

Unlike gap junctions, plasma membrane hemichannels may facilitate cell-cell communication via paracrine signaling. Hemichannels normally remain closed to prevent leakage of substances that could deplete the cell from crucial metabolites or harm neighboring cells [151]. Opening of hemichannels has been demonstrated to play a role in physiology, e.g. in bone where they promote periosteal remodeling processes [152] (reviewed in [153]), or in brain where they may contribute to gliotransmitter release, either as channel facilitating gliotransmitter passage, or as a channel that allows (non-selective) $\mathrm{Ca}^{2+}$ entry triggering release through other pathways [154]. However, most of the evidence currently available links hemichannel opening to pathological conditions [135, 138, 155-159]. Hemichannels can open in response to several signals, including membrane potential changes, intracellular $\mathrm{Ca}^{2+}$ elevation, mechanical stimulation and stress-associated stimuli such as oxidative stress, ischemic or pro-inflammatory conditions and radiation exposure [95, 155, 160-164]. Once hemichannels are open, evidence from various experimental approaches indicates they facilitate the passage and loss of intracellular prostaglandin $\mathrm{E} 2, \mathrm{NAD}^{+}, \mathrm{IP} 3$, glutathione, $\mathrm{ATP}$ and $\mathrm{K}^{+}$, and the entry of $\mathrm{Ca}^{2+}$ and $\mathrm{Na}^{+}[151,155,160-162,165]$. This may lead to downstream responses including NO production, cell proliferation, cell death, NLRP3 inflammasome pathway, and inflammation [34, 95, 134, 166-172]. Some 
of the released messengers, e.g. ATP, may function as a paracrine messenger of bystander signaling thereby expanding radiation-induced biological effects [34, 55, 167]. In addition, open hemichannels may allow direct passage of ROS because of the small size $(<1000 \mathrm{Da})$ of most oxidative stress-inducing molecules and can cause cellular injury or death [160]. Increased hemichannel opening activity was observed in several inflammatory diseases and blocking these channels inhibited the inflammation [171, 173-177]. In addition, specific blocking of hemichannels was suggested to improve gingival wound healing [178], decrease amounts of liver lipids and inflammatory markers in non-alcoholic steatohepatitis in mice [179], reduce cardiac arrhythmogenesis in Duchenne muscular dystrophy mice $[180,181]$ and in MYL-4-related atrial cardiomyopathy and fibrillation [180, 182-184], reduce dopamine neuron loss and microglial activation [185], provide neuroprotection in stroke [186], and protect against seizures in rodents [187].

\section{Connexins and atherosclerosis}

The endothelial cells of the vascular system's major arteries express three prominent $\mathrm{Cx}$ isotypes, namely $\mathrm{Cx} 37, \mathrm{Cx} 40$ and $\mathrm{Cx} 43$, with $\mathrm{Cx} 43$ being the most abundant isoform. In addition, $\mathrm{Cx} 45$ is expressed in the endothelium of the large arteries only. The smooth muscle cells that surround the vascular endothelial cells present mainly $\mathrm{Cx} 43, \mathrm{Cx} 40$ and $\mathrm{Cx} 45$. Five different $\mathrm{Cx}$ isotypes (Cx31.9, Cx37, Cx40, $\mathrm{Cx} 43$, and $\mathrm{Cx} 45$ ) are expressed in the heart, with $\mathrm{Cx} 43$ being the predominant connexin in ventricular myocardium. The turnover of these $\mathrm{Cx}$ proteins is very fast with a half-life ranging from one to five hours. Consequently, $\mathrm{Cx}$ proteins can quickly respond to several conditions due to the plasticity of their expression and the fast dynamics of the formed hemichannels and gap junctions [188]. Therefore, changes in $\mathrm{Cx}$ expression may directly be translated to changes in bystander response (Fig. 2).

Proatherogenic Cxs There is growing evidence that Cx proteins play an important role in atherosclerosis development. Cx43 is normally absent in the aortic endothelium of healthy individuals; however, it can be detected at the plaque shoulder region, which is located close to areas of plaque necrosis, a region known to be prone to plaque rupture, and at branching sites of the arterial tree, which are highly susceptible to atherosclerosis development [189, 190]. High Cx43 expression was reported at regions of disturbed blood flow in rat aortic endothelial cells, and increased $\mathrm{Cx} 43$ expression was also observed in various in vivo studies using a model that simulates human arterial shear stress [191-194]. It is known that a hemodynamic-shear stress environment plays a critical role in atherogenesis by promoting a pro-inflammatory phenotype in the endothelium [195]. Upregulated Cx43 gap junctions between intimal smooth muscle cells were also reported in human coronary artery specimens at regions of intimal thickening and early atheromatous lesions compared to healthy vessels [196]. It has been reported that endothelial Cx43 expression regulates monocyte-endothelial adhesion, which is a crucial initiator of atherosclerosis development, as increased $\mathrm{Cx} 43$ expression enhanced the expression level of cell adhesion proteins, including VCAM-1 [197]. Decreased $\mathrm{Cx} 43$ expression was reported to reduce atherosclerotic lesion formation as well, and to reduce inflammation in low-density lipoprotein receptor-deficient mice, hence to reduce atherosclerosis progression by half [198, 199]. Collectively, these observations suggest that Cx43 is a proatherogenic protein that may stimulate atherosclerosis development.

Next to the alterations in $\mathrm{Cx} 43$ expression and gap junction function during atherosclerosis development, dysfunctional hemichannels have also been suggested to take part in the process. Cx43 hemichannel activity was significantly increased in endothelial cells exposed to pro-inflammatory conditions (IL-1 $\beta / \mathrm{TNF}-\alpha$ ) and high glucose levels, known to cause vascular dysfunction, leading to increased ATPdependent $\mathrm{Ca}^{2+}$ dynamics [200]. In this study, they showed that inhibiting $\mathrm{Cx} 43$ hemichannels prevented endothelial ATP release [200] which induces vascular inflammation and atherosclerosis in mice via the activation of purinergic Receptor Y2 [201].

Atheroprotective Cxs In contrast to Cx43, Cx37 and Cx40 proteins play an atheroprotective role. Endothelial Cx37 and $\mathrm{Cx} 40$ are almost absent in advanced atherosclerotic plaques while present in healthy arteries [190, 202, 203]. Besides, it has been reported that $\mathrm{Cx} 40$-deficient mice, with a coincident reduction in $\mathrm{Cx} 37$, are associated with lower eNOS expression levels in the aortic endothelium, leading to a reduced NO release and smaller endothelium-dependent relaxations of the aorta [204]. Therefore, decreased NO bioavailability has been linked to an increased susceptibility to atherosclerosis [205]. In another study, it was observed that ApoE-/-mice lacking $\mathrm{Cx} 37$ gene (GJA4) developed more aortic lesions than ApoE-/-mice that express Cx37 at normal levels [206]. In vivo and in vitro approaches showed increased recruitment of monocytes and macrophages to the atherosclerotic lesions and increased leucocyte transmigration. Therefore, they suggested that $\mathrm{Cx} 37$ may inhibit atherosclerosis development by tempering leukocyte adhesion [206]. Additionally, a downregulated endothelial Cx37 was observed in response to shear stress, which is known to induce endothelial dysfunction [207]. A recent study demonstrated decreased $\mathrm{Cx} 37$ expression in response to oxidized LDL, a major component of hyperlipidemia and contributor to endothelial injury, in the human monocyte cell line THP1 , which was associated with increased monocyte-endothe- 
lial adhesion, thus potentially promoting atherosclerosis development [208].

Related to $\mathrm{Cx} 40$, it was observed that endothelial-specific deletion of $\mathrm{Cx} 40$ increased CD73-dependent leukocyte-endothelium adhesion, thereby potentially promoting the atherosclerotic process [209]. This study further reported that $\mathrm{Cx} 40$-mediated gap junctional communication between endothelial cells generated anti-inflammatory signals that may contribute to a quiescent non-activated endothelium, thus protecting against atherosclerosis. A recent study reported lowered $\mathrm{Cx} 40$ expression in mice carotid arteries under oscillatory shear stress, which was associated with $\mathrm{NF}_{-} \mathrm{B}$ activation [210]. They further revealed a novel function of $\mathrm{I}_{\mathrm{k}} \mathrm{Ba}-\mathrm{Cx} 40$ interaction involved in controlling $\mathrm{NF}_{-\mathrm{k}} \mathrm{B}$-mediated endothelial cell activation by shear stress in atherogenesis.

Despite these interesting observations discussed above, the relation between altered Cx expression and the atherosclerotic process is not entirely clear yet, especially with respect to the question whether Cxs are causally or consequentially linked to the atherosclerotic process. For instance, a study reported that TGF- $\beta$, a major inflammatory component in the atherosclerotic process, induced upregulation of Cx43 in endothelial cells [211]. In addition, it was found that the atherosclerosis-associated inflammatory markers, TNF-a and INF- $\gamma$, increased Cx43 expression in monocytes [212]. TNF-a treatment also increased $\mathrm{Cx} 43$ at the mRNA level, while it reduced $\mathrm{Cx} 37$ and $\mathrm{Cx} 40$ mRNA in human umbilical vein endothelial cells (HUVEC) [213]. In line with this, endothelial $\mathrm{Cx} 40$ deletion in mice induced spontaneous atherosclerotic plaques in the aortic sinus, without introducing a high-cholesterol diet [209], which support the important role of $\mathrm{Cx}$ proteins in initiating the atherosclerotic process.

\section{Response of connexins and their channels to ionizing radiation exposure}

Cx expression and channel activity have been shown to rapidly change upon intra- and extracellular modifications or in response to stimuli, including ionizing radiation, thereby changing the extent of intercellular communication [188, 214-218]. Alterations in Cx 43 expression were reported in response to low or high doses of IR, and high-LET as well as low-LET radiation exposure. For instance, upregulated $\mathrm{Cx} 43$ expression was reported after exposure to $10 \mathrm{mGy}$ of $\alpha$-particles as well as 4 Gy of $\gamma$-rays in normal human skin fibroblasts, mouse embryo fibroblasts, and rat liver epithelial cells, which was associated with a corresponding increase in gap-junctional intercellular communication [219]. Upregulation of $\mathrm{Cx} 43$ was also observed upon in vivo exposure of cardiac myocytes to heavy-ion irradiation [220-222]. Gamma-ray radiation was furthermore found to induce $\mathrm{Cx} 43$ upregulation in mouse skin [223] and human neonatal foreskin fibroblasts irradiated with single low doses of IR [216]. Similarly, X-rays (5 Gy) increased Cx43 gene expression and protein level in the bEnd 3 endothelial cell line derived from mouse brain capillaries. However, umbilical vein hybrid endothelial cells (EA.hy926) responded oppositely, displaying transient $\mathrm{Cx} 43$ downregulation after 5 Gy X-ray exposure, suggesting that $\mathrm{Cx} 43$ modulation in response to radiation exposure may be cell-line dependent [224]. A recent study also observed that low doses of $\gamma$-rays (10-20 cGy) enhanced Cx43 expression and gap-junctional coupling in U87 glioma cells, and induced $\mathrm{Cx} 43$ overexpression in tumor cells of varying origin [215]. Interestingly, B16-melanoma cells showed $\mathrm{Cx} 43$ hemichannel opening in response to 0.5 Gy $\gamma$-rays, as concluded from ATP release measurements [95]. The mechanisms responsible for $\mathrm{Cx} 43$ alteration in response to IR are not known yet; post-irradiation oxidative stress has been proposed [219], and the nuclear factor of activated T cells (NFAT) together with activator protein (AP1) transcription factors were shown to be responsible for the major activation of the $\mathrm{Cx} 43$ promoter in response to gamma irradiation [216].

Although there is growing evidence indicating the sensitivity of $\mathrm{Cx} 43$ in response to radiation exposure, there is lack of data regarding $\mathrm{Cx}$ modulation in endothelial cells, the primary target site for atherosclerosis development, in response to IR exposure. Moreover, knowledge on radiation-induced alterations in endothelial $\mathrm{C} \times 37$ and $\mathrm{Cx} 40$ is very limited. We found that exposure of immortalized coronary artery and microvascular endothelial cells to low and high doses of X-rays, delivered as a single or fractionated dose, dose-dependently decreased atheroprotective $\mathrm{Cx} 37$ and $\mathrm{Cx} 40$, while increasing proatherogenic Cx43, over a 14 day observation period (Fig. 4). Single and fractionated irradiations were also shown to induce an increase in gene expression and protein levels of the proatherogenic $\mathrm{Cx} 43$ in both coronary artery and microvascular endothelial cells, which was persistent until 14 days after exposure [164]. Similar alterations in Cx expression levels have been reported in the literature in endothelial cells covering atherosclerotic plaques [134, $189,190,202]$. Thus, Cx alterations observed in our study may promote susceptibility to atherosclerosis after IR exposure. Next to $\mathrm{Cx}$ alterations, single and fractionated exposures increased gap junctional communication and induced acute and long-lived Cx43 hemichannel opening persisting over $72 \mathrm{~h}$ after IR in coronary artery and microvascular endothelial cells [164]. As delineated before, excessive hemichannel opening is considered a pathological condition, since it results in loss of cell-essential metabolites and ATP leakage that act in a paracrine manner on surrounding cells. In turn these messengers, with ATP as the principle actor, can activate downstream cellular processes including propagating intercellular $\mathrm{Ca}^{2+}$ 
Fig. 4 Summary scheme of $\mathrm{X}$-ray effects on endothelial connexins (Cxs) and their channels [164]
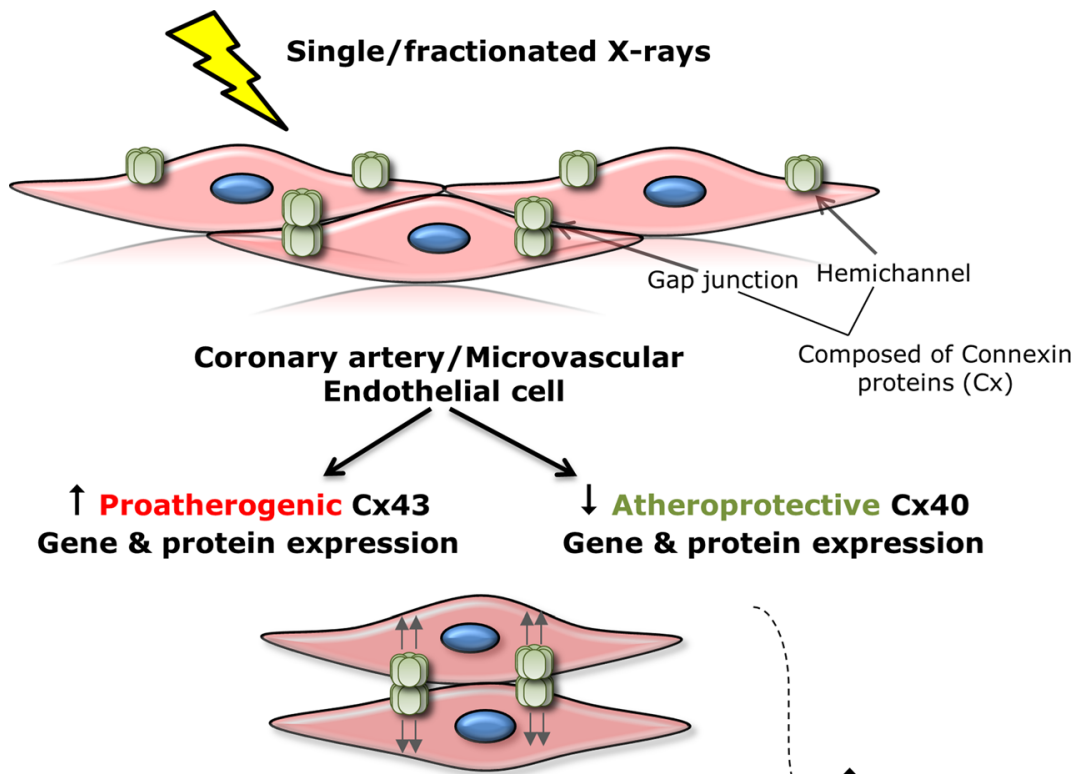

$\uparrow$ Gap junction communication

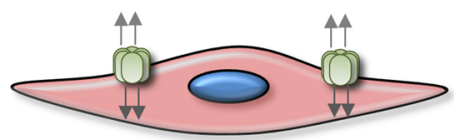

$\uparrow$ Cx43 Hemichannel opening<smiles>C1=[In][I-]=C1</smiles>

$\uparrow$ risk of endothelial cell dysfunction

$\uparrow$ transfer of radiation damaging signals

$\uparrow$ risk of endothelial cell damage waves, oxidative stress responses, apoptosis, NLRP3 inflammasome pathway activation and inflammation (50-52), which are to known to be involved in the pathogenesis of radiation-induced atherosclerosis. Moreover, radiation-induced increased endothelial gap-junctional coupling and hemichannel function may spread radiation damaging responses to neighboring cells, possibly amplifying endothelial cell damage (Fig. 2) [46, 55, 166, 214, 219, 225-227]. Together, these findings suggest a possible mechanism of radiation-induced atherosclerosis (Fig. 4), which may guide us in further improving our understanding of $\mathrm{Cx}$ proteins as a potential target to prevent radiation-induced cardiovascular complications. Interestingly, we found that the $\mathrm{Cx} 43$ hemichannel-inhibiting peptide TAT-Gap19 mitigated radiation-induced endothelial cell damage by reducing oxidative stress, cell death, premature cell senescence and pro-inflammatory and pathological factors like IL-1 $\beta$, IL-8, VCAM-1, MCP-1 and endothelin-1 in immortalized coronary artery and microvascular endothelial cells [228]. Therefore, targeting $\mathrm{Cx} 43$ hemichannels may hold potential to protect against radiation-induced endothelial cell damage.

\section{Conclusion}

Growing evidence indicates an excess risk of radiationrelated side effects such as late occurring cardiovascular diseases, especially atherosclerosis. However, the exact pathophysiological mechanisms underlying radiationinduced atherosclerosis are not completely understood, possibly resulting in improper radiation protection. Ionizing radiation induces cellular effects such as DNA damage, oxidative stress, inflammation, apoptosis, and premature cell senescence which may induce endothelial cell dysfunction, a primary marker for atherosclerosis. Intercellular communication through gap junctions and hemichannels, which propagate radiation-induced bystander effects, may modulate the endothelial response to ionizing radiation, and therefore the atherosclerotic process. Although Cxs were shown to be altered by radiation exposure and to play a role in atherosclerotic development, current evidence linking the two processes is still lacking. More studies are needed to clarify the role of Cxs and their channels in radiation-induced atherosclerosis, possibly leading to new opportunities for targeting connexins and its channels. 
Author contributions Raghda Ramadan: partial fulfilment of thesis requirement of RR. An Aerts and Luc Leybaert shared senior authorship.

Funding RR is supported by a doctoral SCK CEN/Ghent University grant; LL research is supported by the Fund for Scientific Research Flanders, Belgium, Grant no. G.0407.20 N on bystander communication and connexin signaling.

\section{Compliance with ethical standards}

Conflict of interest The authors declare that they have no competing interests.

Consent for publication All authors read and approved the final manuscript for publication.

Open Access This article is distributed under the terms of the Creative Commons Attribution 4.0 International License (http://creativeco mmons.org/licenses/by/4.0/), which permits use, duplication, adaptation, distribution and reproduction in any medium or format, as long as you give appropriate credit to the original author(s) and the source, provide a link to the Creative Commons license and indicate if changes were made.

\section{References}

1. Gaziano T, Reddy KS, Paccaud F (2006) Cardiovascular disease disease control priorities in developing countries. The International Bank for Reconstruction and Development, Washington (DC)

2. Ramadan R (2019) The role of connexin-mediated intercellular communication in radiation-induced atherosclerosis, $\mathrm{PhD}$ thesis. Gent University

3. Yusuf S, Reddy S, Ounpuu S, Anand S (2001) Global burden of cardiovascular diseases: part I: general considerations, the epidemiologic transition, risk factors, and impact of urbanization. Circulation 104(22):2746-2753

4. Darby S, McGale P, Peto R, Granath F, Hall P, Ekbom A (2003) Mortality from cardiovascular disease more than 10 years after radiotherapy for breast cancer: nationwide cohort study of 90000 Swedish women. BMJ 326(7383):256-257

5. Darby SC, Ewertz M, McGale P, Bennet AM, Blom-Goldman U, Bronnum D, Correa C, Cutter D, Gagliardi G, Gigante B, Jensen MB, Nisbet A, Peto R, Rahimi K, Taylor C, Hall P (2013) Risk of ischemic heart disease in women after radiotherapy for breast cancer. N Engl J Med 368(11):987-998. https://doi.org/10.1056/ NEJMoa1209825

6. Aleman BM, Moser EC, Nuver J, Suter TM, Maraldo MV, Specht L, Vrieling C, Darby SC (2014) Cardiovascular disease after cancer therapy. EJC Suppl 12(1):18-28. https://doi.org/10.1016/j. ejcsup.2014.03.002

7. Baselet B, Rombouts C, Benotmane AM, Baatout S, Aerts A (2016) Cardiovascular diseases related to ionizing radiation: the risk of low-dose exposure (Review). Int J Mol Med 38(6):16231641. https://doi.org/10.3892/ijmm.2016.2777

8. Yusuf SW, Sami S, Daher IN (2011) Radiation-induced heart disease: a clinical update. Cardiol Res Pract 2011:317659. https ://doi.org/10.4061/2011/317659

9. ICRP, Stewart FA, Akleyev AV, Hauer-Jensen M, Hendry JH, Kleiman NJ, Macvittie TJ, Aleman BM, Edgar AB, Mabuchi K,
Muirhead CR, Shore RE, Wallace WH (2012) ICRP publication 118: ICRP statement on tissue reactions and early and late effects of radiation in normal tissues and organs-threshold doses for tissue reactions in a radiation protection context. Ann ICRP 41 (1-2):1-322. Doi:https://doi.org/10.1016/j.icrp.2012.02.001

10. Baker JE, Moulder JE, Hopewell JW (2011) Radiation as a risk factor for cardiovascular disease. Antioxid Redox Signal 15(7):1945-1956. https://doi.org/10.1089/ars.2010.3742

11. Kreuzer M, Auvinen A, Cardis E, Hall J, Jourdain JR, Laurier D, Little MP, Peters A, Raj K, Russell NS, Tapio S, Zhang W, Gomolka M (2015) Low-dose ionising radiation and cardiovascular diseases-Strategies for molecular epidemiological studies in Europe. Mutat Res Rev Mutat Res 764:90-100. https://doi. org/10.1016/j.mrrev.2015.03.002

12. Boaventura P, Duraes C, Mendes A, Costa NR, Chora I, Ferreira S, Araujo E, Lopes P, Rosa G, Marques P, Tavares S, Chaves V, Bettencourt P, Oliveira I, Costa F, Ramos I, Teles MJ, Guimaraes JT, Sobrinho-Simoes M, Soares P (2018) Is Low-dose radiation exposure a risk factor for atherosclerotic disease? Radiat Res 189(4):418-424. https://doi.org/10.1667/RR14942.1

13. Miller KD, Siegel RL, Lin CC, Mariotto AB, Kramer JL, Rowland JH, Stein KD, Alteri R, Jemal A (2016) Cancer treatment and survivorship statistics. CA Cancer J Clin 66(4):271-289. https://doi.org/10.3322/caac.21349

14. Chargari C, Riet F, Mazevet M, Morel E, Lepechoux C, Deutsch E (2013) Complications of thoracic radiotherapy. Presse Med 42(9 Pt 2):e342-351. https://doi.org/10.1016/j.lpm.2013.06.012

15. Shimizu Y, Kodama K, Nishi N, Kasagi F, Suyama A, Soda M, Grant EJ, Sugiyama H, Sakata R, Moriwaki H, Hayashi M, Konda M, Shore RE (2010) Radiation exposure and circulatory disease risk: Hiroshima and Nagasaki atomic bomb survivor data, 1950-2003. BMJ 340:b5349. https://doi.org/10.1136/bmj. b5349

16. Cheng YJ, Nie XY, Ji CC, Lin XX, Liu LJ, Chen XM, Yao H, Wu SH (2017) Long-term cardiovascular risk after radiotherapy in women with breast cancer. J Am Heart Assoc. https://doi. org/10.1161/JAHA.117.005633

17. McGale P, Darby SC, Hall P, Adolfsson J, Bengtsson NO, Bennet AM, Fornander T, Gigante B, Jensen MB, Peto R, Rahimi K, Taylor CW, Ewertz M (2011) Incidence of heart disease in 35,000 women treated with radiotherapy for breast cancer in Denmark and Sweden. Radiother Oncol 100(2):167-175. https ://doi.org/10.1016/j.radonc.2011.06.016

18. Little MP (2016) Radiation and circulatory disease. Mutat Res 770(Pt B):299-318. https://doi.org/10.1016/j.mrrev.2016.07.008

19. Little MP, Azizova TV, Bazyka D, Bouffler SD, Cardis E, Chekin $S$, Chumak VV, Cucinotta FA, de Vathaire F, Hall P, Harrison JD, Hildebrandt G, Ivanov V, Kashcheev VV, Klymenko SV, Kreuzer M, Laurent O, Ozasa K, Schneider T, Tapio S, Taylor AM, Tzoulaki I, Vandoolaeghe WL, Wakeford R, Zablotska LB, Zhang W, Lipshultz SE (2012) Systematic review and meta-analysis of circulatory disease from exposure to low-level ionizing radiation and estimates of potential population mortality risks. Environ Health Perspect 120(11):1503-1511. https://doi. org/10.1289/ehp.1204982

20. Barjaktarovic Z, Anastasov N, Azimzadeh O, Sriharshan A, Sarioglu H, Ueffing M, Tammio H, Hakanen A, Leszczynski D, Atkinson MJ, Tapio S (2013) Integrative proteomic and microRNA analysis of primary human coronary artery endothelial cells exposed to low-dose gamma radiation. Radiat Environ Biophys 52(1):87-98. https://doi.org/10.1007/s00411-012-0439-4

21. Monceau V, Meziani L, Strup-Perrot C, Morel E, Schmidt M, Haagen J, Escoubet B, Dorr W, Vozenin MC (2013) Enhanced sensitivity to low dose irradiation of ApoE-/- mice mediated by early pro-inflammatory profile and delayed activation of 
the TGFbetal cascade involved in fibrogenesis. PLoS ONE 8(2):e57052. https://doi.org/10.1371/journal.pone.0057052

22. Mitchel RE, Hasu M, Bugden M, Wyatt H, Little MP, Gola A, Hildebrandt G, Priest ND, Whitman SC (2011) Low-dose radiation exposure and atherosclerosis in $\operatorname{ApoE}(-) /(-)$ mice. Radiat Res 175(5):665-676. https://doi.org/10.1667/RR2176.1

23. Azimzadeh O, Azizova T, Merl-Pham J, Subramanian V, Bakshi MV, Moseeva M, Zubkova O, Hauck SM, Anastasov N, Atkinson MJ, Tapio S (2017) A dose-dependent perturbation in cardiac energy metabolism is linked to radiation-induced ischemic heart disease in Mayak nuclear workers. Oncotarget 8(6):9067-9078. https://doi.org/10.18632/oncotarget.10424

24. Cervelli T, Panetta D, Navarra T, Andreassi MG, Basta G, Galli A, Salvadori PA, Picano E, Del Turco S (2014) Effects of single and fractionated low-dose irradiation on vascular endothelial cells. Atherosclerosis 235(2):510-518. https://doi. org/10.1016/j.atherosclerosis.2014.05.932

25. Wang J, Boerma M, Fu Q, Hauer-Jensen M (2007) Significance of endothelial dysfunction in the pathogenesis of early and delayed radiation enteropathy. World J Gastroenterol 13(22):3047-3055

26. Stewart FA, Heeneman S, Te Poele J, Kruse J, Russell NS, Gijbels M, Daemen M (2006) Ionizing radiation accelerates the development of atherosclerotic lesions in ApoE-/- mice and predisposes to an inflammatory plaque phenotype prone to hemorrhage. Am J Pathol 168(2):649-658. https://doi. org/10.2353/ajpath.2006.050409

27. Borghini A, Gianicolo EA, Picano E, Andreassi MG (2013) Ionizing radiation and atherosclerosis: current knowledge and future challenges. Atherosclerosis 230(1):40-47. https://doi. org/10.1016/j.atherosclerosis.2013.06.010

28. Sievert W, Trott KR, Azimzadeh O, Tapio S, Zitzelsberger H, Multhoff G (2015) Late proliferating and inflammatory effects on murine microvascular heart and lung endothelial cells after irradiation. Radiother Oncol 117(2):376-381. https://doi. org/10.1016/j.radonc.2015.07.029

29. Di Maggio FM, Minafra L, Forte GI, Cammarata FP, Lio D, Messa C, Gilardi MC, Bravata V (2015) Portrait of inflammatory response to ionizing radiation treatment. J Inflamm (Lond) 12:14. https://doi.org/10.1186/s12950-015-0058-3

30. Hoving S, Heeneman S, Gijbels MJ, te Poele JA, Russell NS, Daemen MJ, Stewart FA (2008) Single-dose and fractionated irradiation promote initiation and progression of atherosclerosis and induce an inflammatory plaque phenotype in $\mathrm{ApoE}(-/-)$ mice. Int J Radiat Oncol Biol Phys 71(3):848-857. https://doi. org/10.1016/j.ijrobp.2008.02.031

31. Baselet B, Sonveaux P, Baatout S, Aerts A (2019) Pathological effects of ionizing radiation: endothelial activation and dysfunction. Cell Mol Life Sci 76(4):699-728. https://doi. org/10.1007/s00018-018-2956-z

32. Baselet B, Ramadan R, Benotmane AM, Sonveaux P, Baatout S, Aerts A (2017) Selected endothelial responses after ionizing radiation Exposure. In: Lenasi $\mathrm{H}$ (ed) Endothelial dysfunction. IntechOpen, London. https://doi.org/10.5772/intechopen .72386

33. Hei TK, Zhou H, Ivanov VN, Hong M, Lieberman HB, Brenner DJ, Amundson SA, Geard CR (2008) Mechanism of radiationinduced bystander effects: a unifying model. J Pharm Pharmacol 60(8):943-950. https://doi.org/10.1211/jpp.60.8.0001

34. Decrock E, Hoorelbeke D, Ramadan R, Delvaeye T, De Bock M, Wang N, Krysko DV, Baatout S, Bultynck G, Aerts A, Vinken M (1864) Leybaert L (2017) Calcium, oxidative stress and connexin channels, a harmonious orchestra directing the response to radiotherapy treatment? Biochim Biophys Acta 6:1099-1120. https://doi.org/10.1016/j.bbamcr.2017.02.007
35. Blyth BJ, Sykes PJ (2011) Radiation-induced bystander effects: what are they, and how relevant are they to human radiation exposures? Radiat Res 176(2):139-157

36. Wang R, Zhou T, Liu W, Zuo L (2018) Molecular mechanism of bystander effects and related abscopal/cohort effects in cancer therapy. Oncotarget 9(26):18637-18647. https://doi. org/10.18632/oncotarget.24746

37. Wright EG (2010) Manifestations and mechanisms of non-targeted effects of ionizing radiation. Mutat Res 687(1-2):28-33. https://doi.org/10.1016/j.mrfmmm.2010.01.014

38. Morgan WF, Day JP, Kaplan MI, McGhee EM, Limoli CL (1996) Genomic instability induced by ionizing radiation. Radiat Res 146(3):247-258

39. Stamell EF, Wolchok JD, Gnjatic S, Lee NY, Brownell I (2013) The abscopal effect associated with a systemic anti-melanoma immune response. Int J Radiat Oncol Biol Phys 85(2):293-295. https://doi.org/10.1016/j.ijrobp.2012.03.017

40. Nagasawa H, Little JB (1992) Induction of sister chromatid exchanges by extremely low doses of alpha-particles. Cancer Res 52(22):6394-6396

41. Deshpande A, Goodwin EH, Bailey SM, Marrone BL, Lehnert BE (1996) Alpha-particle-induced sister chromatid exchange in normal human lung fibroblasts: evidence for an extranuclear target. Radiat Res 145(3):260-267

42. Mothersill C, Seymour C (2001) Radiation-induced bystander effects: past history and future directions. Radiat Res 155(6):759-767

43. Verma N, Tiku AB (2017) Significance and nature of bystander responses induced by various agents. Mutat Res 773:104-121. https://doi.org/10.1016/j.mrrev.2017.05.003

44. Hatzi VI, Laskaratou DA, Mavragani IV, Nikitaki Z, Mangelis A, Panayiotidis MI, Pantelias GE, Terzoudi GI, Georgakilas AG (2015) Non-targeted radiation effects in vivo: a critical glance of the future in radiobiology. Cancer Lett 356(1):34-42. https://doi. org/10.1016/j.canlet.2013.11.018

45. Mancuso M, Pasquali E, Giardullo P, Leonardi S, Tanori M, Di Majo V, Pazzaglia S, Saran A (2012) The radiation bystander effect and its potential implications for human health. Curr Mol Med 12(5):613-624. https://doi.org/10.2174/156652412800620 011

46. Zhou H, Randers-Pehrson G, Waldren CA, Vannais D, Hall EJ, Hei TK (2000) Induction of a bystander mutagenic effect of alpha particles in mammalian cells. Proc Natl Acad Sci USA 97(5):2099-2104. https://doi.org/10.1073/pnas.030420797

47. Belyakov OV, Malcolmson AM, Folkard M, Prise KM, Michael BD (2001) Direct evidence for a bystander effect of ionizing radiation in primary human fibroblasts. Br J Cancer 84(5):674-679. https://doi.org/10.1054/bjoc.2000.1665

48. Lorimore SA, Chrystal JA, Robinson JI, Coates PJ, Wright EG (2008) Chromosomal instability in unirradiated hemaopoietic cells induced by macrophages exposed in vivo to ionizing radiation. Cancer Res 68(19):8122-8126. https://doi. org/10.1158/0008-5472.CAN-08-0698

49. Sedelnikova OA, Nakamura A, Kovalchuk O, Koturbash I, Mitchell SA, Marino SA, Brenner DJ, Bonner WM (2007) DNA double-strand breaks form in bystander cells after microbeam irradiation of three-dimensional human tissue models. Cancer Res 67(9):4295-4302. https://doi.org/10.1158/0008-5472. CAN-06-4442

50. Belyakov OV, Mitchell SA, Parikh D, Randers-Pehrson G, Marino SA, Amundson SA, Geard CR, Brenner DJ (2005) Biological effects in unirradiated human tissue induced by radiation damage up to $1 \mathrm{~mm}$ away. Proc Natl Acad Sci USA 102(40):14203-14208. https://doi.org/10.1073/pnas.0505020102 
51. Prise KM, Belyakov OV, Folkard M, Michael BD (1998) Studies of bystander effects in human fibroblasts using a charged particle microbeam. Int J Radiat Biol 74(6):793-798

52. Han W, Chen S, Yu KN, Wu L (2010) Nitric oxide mediated DNA double strand breaks induced in proliferating bystander cells after alpha-particle irradiation. Mutat Res 684(1-2):81-89. https://doi.org/10.1016/j.mrfmmm.2009.12.004

53. Li J, He M, Shen B, Yuan D, Shao C (2013) Alpha particle-induced bystander effect is mediated by ROS via a p53-dependent SCO2 pathway in hepatoma cells. Int J Radiat Biol 89(12):1028-1034. https://doi.org/10.3109/09553 002.2013 .817706

54. Yang S, Xu J, Shao W, Geng C, Li J, Guo F, Miao H, Shen W, Ye T, Liu Y, Xu H, Zhang X (2015) Radiation-induced bystander effects in a549 cells exposed to $6 \mathrm{MV}$ x-rays. Cell Biochem Biophys 72(3):877-882. https://doi.org/10.1007/s12013-015-0555-2

55. Hoorelbeke D, Decrock E, De Smet M, De Bock M, Descamps B, Van Haver V, Delvaeye T, Krysko DV, Vanhove C, Bultynck G, Leybaert L (2020) Cx43 channels and signaling via IP3/Ca(2+), ATP, and ROS/NO propagate radiation-induced DNA damage to non-irradiated brain microvascular endothelial cells. Cell Death Dis 11(3):194. https://doi.org/10.1038/s41419-020-2392-5

56. Gaugler MH, Neunlist M, Bonnaud S, Aubert P, Benderitter M, Paris F (2007) Intestinal epithelial cell dysfunction is mediated by an endothelial-specific radiation-induced bystander effect. Radiat Res 167(2):185-193

57. Ojima M, Ban N, Kai M (2008) DNA double-strand breaks induced by very low X-ray doses are largely due to bystander effects. Radiat Res 170(3):365-371. https://doi.org/10.1667/ RR1255.1

58. Ke FC, Fang SH, Lee MT, Sheu SY, Lai SY, Chen YJ, Huang FL, Wang PS, Stocco DM, Hwang JJ (2005) Lindane, a gap junction blocker, suppresses FSH and transforming growth factor beta1induced connexin 43 gap junction formation and steroidogenesis in rat granulosa cells. J Endocrinol 184(3):555-566. https://doi. org/10.1677/joe. 1.05776

59. Seymour CB, Mothersill C (2000) Relative contribution of bystander and targeted cell killing to the low-dose region of the radiation dose-response curve. Radiat Res 153(5 Pt 1):508-511

60. Gow MD, Seymour CB, Byun SH, Mothersill CE (2008) Effect of dose rate on the radiation-induced bystander response. Phys Med Biol 53(1):119-132. https://doi.org/10.1088/0031-9155/53/1/008

61. Mothersill C, Seymour CB (2002) Bystander and delayed effects after fractionated radiation exposure. Radiat Res 158(5):626-633

62. Soleymanifard S, Toossi MT, Samani RK, Mohebbi S (2014) Investigation of the bystander effect in MRC5 cells after acute and fractionated irradiation in vitro. J Med Phys 39(2):93-97. https://doi.org/10.4103/0971-6203.131282

63. Azzam EI, De Toledo SM, Spitz DR, Little JB (2002) Oxidative metabolism modulates signal transduction and micronucleus formation in bystander cells from alpha-particle-irradiated normal human fibroblast cultures. Cancer Res 62(19):5436-5442

64. Lorimore SA, Kadhim MA, Pocock DA, Papworth D, Stevens DL, Goodhead DT, Wright EG (1998) Chromosomal instability in the descendants of unirradiated surviving cells after alphaparticle irradiation. Proc Natl Acad Sci USA 95(10):5730-5733

65. Wright EG (1998) Radiation-induced genomic instability in haemopoietic cells. Int J Radiat Biol 74(6):681-687

66. Mackonis EC, Suchowerska N, Zhang M, Ebert M, McKenzie DR, Jackson M (2007) Cellular response to modulated radiation fields. Phys Med Biol 52(18):5469-5482. https://doi. org/10.1088/0031-9155/52/18/001

67. Maguire P, Mothersill C, McClean B, Seymour C, Lyng FM (2007) Modulation of radiation responses by pre-exposure to irradiated cell conditioned medium. Radiat Res 167(4):485-492. https://doi.org/10.1667/RR0159.1
68. Matsumoto H, Takahashi A, Ohnishi T (2004) Radiationinduced adaptive responses and bystander effects. Biol Sci Space 18(4):247-254. https://doi.org/10.2187/bss.18.247

69. Ojima M, Eto H, Ban N, Kai M (2011) Radiation-induced bystander effects induce radioadaptive response by low-dose radiation. Radiat Prot Dosimetry 146(1-3):276-279. https://doi. org/10.1093/rpd/ncr169

70. Xiao L, Liu W, Li J, Xie Y, He M, Fu J, Jin W, Shao C (2014) Irradiated U937 cells trigger inflammatory bystander responses in human umbilical vein endothelial cells through the p38 pathway. Radiat Res 182(1):111-121. https://doi.org/10.1667/RR137 36.1

71. Libby P, Ridker PM, Maseri A (2002) Inflammation and atherosclerosis. Circulation 105(9):1135-1143

72. Florence JM, Krupa A, Booshehri LM, Allen TC, Kurdowska AK (2017) Metalloproteinase-9 contributes to endothelial dysfunction in atherosclerosis via protease activated receptor-1. PLoS ONE 12(2):e0171427. https://doi.org/10.1371/journ al.pone. 0171427

73. Koturbash I, Loree J, Kutanzi K, Koganow C, Pogribny I, Kovalchuk O (2008) In vivo bystander effect: cranial X-irradiation leads to elevated DNA damage, altered cellular proliferation and apoptosis, and increased p53 levels in shielded spleen. Int J Radiat Oncol Biol Phys 70(2):554-562. https://doi.org/10.1016/j. ijrobp.2007.09.039

74. Mohye El-Din AA, Abdelrazzak AB, Ahmed MT, El-Missiry MA (2017) Radiation induced bystander effects in the spleen of cranially-irradiated rats. Br J Radiol 90(1080):20170278. https ://doi.org/10.1259/bjr.20170278

75. Khan MA, Van Dyk J, Yeung IW, Hill RP (2003) Partial volume rat lung irradiation; assessment of early DNA damage in different lung regions and effect of radical scavengers. Radiother Oncol 66(1):95-102

76. Fardid R, Salajegheh A, Mosleh-Shirazi MA, Sharifzadeh S, Okhovat MA, Najafi M, Rezaeyan A, Abaszadeh A (2017) Melatonin ameliorates the production of COX-2, iNOS, and the formation of 8-OHdG in non-targeted lung tissue after pelvic irradiation. Cell J 19(2):324-331. https://doi.org/10.22074/cellj .2016 .3857

77. Koturbash I, Boyko A, Rodriguez-Juarez R, McDonald RJ, Tryndyak VP, Kovalchuk I, Pogribny IP, Kovalchuk O (2007) Role of epigenetic effectors in maintenance of the long-term persistent bystander effect in spleen in vivo. Carcinogenesis 28(8):1831-1838. https://doi.org/10.1093/carcin/bgm053

78. Camphausen K, Moses MA, Menard C, Sproull M, Beecken WD, Folkman J, O'Reilly MS (2003) Radiation abscopal antitumor effect is mediated through p53. Cancer Res 63(8):1990-1993

79. Mancuso M, Pasquali E, Leonardi S, Tanori M, Rebessi S, Di Majo V, Pazzaglia S, Toni MP, Pimpinella M, Covelli V, Saran A (2008) Oncogenic bystander radiation effects in Patched heterozygous mouse cerebellum. Proc Natl Acad Sci USA 105(34):12445-12450. https://doi.org/10.1073/pnas.0804186105

80. Mancuso M, Pasquali E, Leonardi S, Rebessi S, Tanori M, Giardullo P, Borra F, Pazzaglia S, Naus CC, Di Majo V, Saran A (2011) Role of connexin43 and ATP in long-range bystander radiation damage and oncogenesis in vivo. Oncogene 30(45):4601-4608. https://doi.org/10.1038/onc.2011.176

81. Ohba K, Omagari K, Nakamura T, Ikuno N, Saeki S, Matsuo I, Kinoshita H, Masuda J, Hazama H, Sakamoto I, Kohno S (1998) Abscopal regression of hepatocellular carcinoma after radiotherapy for bone metastasis. Gut 43(4):575-577

82. Kaminski JM, Shinohara E, Summers JB, Niermann KJ, Morimoto A, Brousal J (2005) The controversial abscopal effect. Cancer Treat Rev 31(3):159-172. https://doi.org/10.1016/j. ctrv.2005.03.004 
83. Parsons WB Jr, Watkins CH, Pease GL, Childs DS Jr (1954) Changes in sternal marrow following roentgen-ray therapy to the spleen in chronic granulocytic leukemia. Cancer 7(1):179-189

84. Yilmaz MT, Elmali A, Yazici G (2019) Abscopal effect, from myth to reality: from radiation oncologists' perspective. Cureus 11(1):e3860. https://doi.org/10.7759/cureus.3860

85. Dagoglu N, Karaman S, Caglar HB, Oral EN (2019) Abscopal effect of radiotherapy in the immunotherapy era: systematic review of reported cases. Cureus 11(2):e4103. https://doi. org/10.7759/cureus.4103

86. Liu Y, Dong Y, Kong L, Shi F, Zhu H, Yu J (2018) Abscopal effect of radiotherapy combined with immune checkpoint inhibitors. J Hematol Oncol 11(1):104. https://doi.org/10.1186/s1304 5-018-0647-8

87. Brenner DJ, Curtis RE, Hall EJ, Ron E (2000) Second malignancies in prostate carcinoma patients after radiotherapy compared with surgery. Cancer 88(2):398-406

88. Morton LM, Onel K, Curtis RE, Hungate EA, Armstrong GT (2014) The rising incidence of second cancers: patterns of occurrence and identification of risk factors for children and adults. Am Soc Clin Oncol Educ Book. https://doi.org/10.14694/EdBoo k_AM.2014.34.e57

89. Dent SF, Klaassen D, Pater JL, Zee B, Whitehead M (2000) Second primary malignancies following the treatment of early stage ovarian cancer: update of a study by the National Cancer Institute of Canada-Clinical Trials Group (NCIC-CTG). Ann Oncol 11(1):65-68

90. Birgisson H, Pahlman L, Gunnarsson U, Glimelius B (2005) Occurrence of second cancers in patients treated with radiotherapy for rectal cancer. J Clin Oncol 23(25):6126-6131. https ://doi.org/10.1200/JCO.2005.02.543

91. Marin A, Martin M, Linan O, Alvarenga F, Lopez M, Fernandez L, Buchser D, Cerezo L (2015) Bystander effects and radiotherapy. Rep Pract Oncol Radiother 20(1):12-21. https://doi. org/10.1016/j.rpor.2014.08.004

92. Yahyapour R, Salajegheh A, Safari A, Amini P, Rezaeyan A, Amraee A, Najafi M (2018) Radiation-induced non-targeted effect and carcinogenesis; implications in clinical radiotherapy. J Biomed Phys Eng 8(4):435-446

93. Little JB (2006) Cellular radiation effects and the bystander response. Mutat Res 597(1-2):113-118. https://doi. org/10.1016/j.mrfmmm.2005.12.001

94. Azzam EI, de Toledo SM, Little JB (2001) Direct evidence for the participation of gap junction-mediated intercellular communication in the transmission of damage signals from alpha -particle irradiated to nonirradiated cells. Proc Natl Acad Sci USA 98(2):473-478. https://doi.org/10.1073/pnas.011417098

95. Ohshima Y, Tsukimoto M, Harada H, Kojima S (2012) Involvement of connexin43 hemichannel in ATP release after $\gamma$-irradiation. J Radiat Res 53(4):551-557. https://doi. org/10.1093/jrr/rrs014

96. Xu S, Wang J, Ding N, Hu W, Zhang X, Wang B, Hua J, Wei W, Zhu Q (2015) Exosome-mediated microRNA transfer plays a role in radiation-induced bystander effect. RNA Biol 12(12):13551363. https://doi.org/10.1080/15476286.2015.1100795

97. Tsukimoto M, Homma T, Ohshima Y, Kojima S (2010) Involvement of purinergic signaling in cellular response to gamma radiation. Radiat Res 173(3):298-309. https://doi.org/10.1667/RR173 2.1

98. Tsukimoto M (2015) Purinergic signaling is a novel mechanism of the cellular response to ionizing radiation. Biol Pharm Bull 38(7):951-959. https://doi.org/10.1248/bpb.b15-00062

99. Kojima S, Ohshima Y, Nakatsukasa H, Tsukimoto M (2017) Role of ATP as a key signaling molecule mediating radiation-induced biological effects. Dose Response 15(1):1559325817690638. https://doi.org/10.1177/1559325817690638
100. Mladenov E, Li F, Zhang L, Klammer H, Iliakis G (2018) Intercellular communication of DNA damage and oxidative status underpin bystander effects. Int J Radiat Biol. https://doi. org/10.1080/09553002.2018.1434323

101. Klammer H, Mladenov E, Li F, Iliakis G (2015) Bystander effects as manifestation of intercellular communication of DNA damage and of the cellular oxidative status. Cancer Lett 356(1):58-71. https://doi.org/10.1016/j.canlet.2013.12.017

102. Kattoor AJ, Pothineni NVK, Palagiri D, Mehta JL (2017) Oxidative stress in atherosclerosis. Curr Atheroscler Rep 19(11):42. https://doi.org/10.1007/s11883-017-0678-6

103. Victor VM, Rocha M, Sola E, Banuls C, Garcia-Malpartida K, Hernandez-Mijares A (2009) Oxidative stress, endothelial dysfunction and atherosclerosis. Curr Pharm Des 15(26):2988-3002. https://doi.org/10.2174/138161209789058093

104. Prise KM, O’Sullivan JM (2009) Radiation-induced bystander signalling in cancer therapy. Nat Rev Cancer 9(5):351-360. https ://doi.org/10.1038/nrc2603

105. Lyng FM, Howe OL, McClean B (2011) Reactive oxygen species-induced release of signalling factors in irradiated cells triggers membrane signalling and calcium influx in bystander cells. Int J Radiat Biol 87(7):683-695. https://doi.org/10.3109/09553 002.2010 .549533

106. Zhou H, Ivanov VN, Gillespie J, Geard CR, Amundson SA, Brenner DJ, Yu Z, Lieberman HB, Hei TK (2005) Mechanism of radiation-induced bystander effect: role of the cyclooxygenase-2 signaling pathway. Proc Natl Acad Sci USA 102(41):1464114646. https://doi.org/10.1073/pnas.0505473102

107. Zhou H, Ivanov VN, Lien YC, Davidson M, Hei TK (2008) Mitochondrial function and nuclear factor-kappaB-mediated signaling in radiation-induced bystander effects. Cancer Res 68(7):22332240. https://doi.org/10.1158/0008-5472.CAN-07-5278

108. Yakovlev VA (2015) Role of nitric oxide in the radiationinduced bystander effect. Redox Biol 6:396-400. https://doi. org/10.1016/j.redox.2015.08.018

109. Najafi M, Fardid R, Hadadi G, Fardid M (2014) The mechanisms of radiation-induced bystander effect. J Biomed Phys Eng 4(4):163-172

110. Kojima S (2014) Involvement of ATP in radiation-induced bystander effect as a signaling molecule. Yakugaku Zasshi 134(6):743-749. https://doi.org/10.1248/yakushi.14-00034

111. Ilnytskyy Y, Koturbash I, Kovalchuk O (2009) Radiation-induced bystander effects in vivo are epigenetically regulated in a tissuespecific manner. Environ Mol Mutagen 50(2):105-113. https:// doi.org/10.1002/em.20440

112. Koturbash I, Rugo RE, Hendricks CA, Loree J, Thibault B, Kutanzi K, Pogribny I, Yanch JC, Engelward BP, Kovalchuk O (2006) Irradiation induces DNA damage and modulates epigenetic effectors in distant bystander tissue in vivo. Oncogene 25(31):4267-4275. https://doi.org/10.1038/sj.onc.1209467

113. Nelson G, Wordsworth J, Wang C, Jurk D, Lawless C, MartinRuiz C, von Zglinicki T (2012) A senescent cell bystander effect: senescence-induced senescence. Aging Cell 11(2):345-349. https ://doi.org/10.1111/j.1474-9726.2012.00795.x

114. Nelson G, Kucheryavenko O, Wordsworth J, von Zglinicki T (2018) The senescent bystander effect is caused by ROS-activated NF-kappaB signalling. Mech Ageing Dev 170:30-36. https ://doi.org/10.1016/j.mad.2017.08.005

115. Tchkonia T, Zhu Y, van Deursen J, Campisi J, Kirkland JL (2013) Cellular senescence and the senescent secretory phenotype: therapeutic opportunities. J Clin Invest 123(3):966-972. https://doi. org/10.1172/JCI64098

116. Peng Y, Zhang M, Zheng L, Liang Q, Li H, Chen JT, Guo H, Yoshina S, Chen YZ, Zhao X, Wu X, Liu B, Mitani S, Yu JS, Xue D (2017) Cysteine protease cathepsin B mediates radiationinduced bystander effects. Nature 547(7664):458-462. https:// doi.org/10.1038/nature23284 
117. Hoefen RJ, Berk BC (2002) The role of MAP kinases in endothelial activation. Vascul Pharmacol 38(5):271-273

118. Bryk D, Olejarz W, Zapolska-Downar D (2014) Mitogen-activated protein kinases in atherosclerosis. Postepy Hig Med Dosw (Online) 68:10-22. https://doi.org/10.5604/17322693.1085463

119. He H, Guo F, Li Y, Saaoud F, Kimmis BD, Sandhu J, Fan M, Maulik D, Lessner S, Papasian CJ, Fan D, Jiang Z, Fu M (2016) Adiporedoxin suppresses endothelial activation via inhibiting MAPK and NF-kappaB signaling. Sci Rep 6:38975. https://doi. org/10.1038/srep38975

120. Pamukcu B, Lip GY, Shantsila E (2011) The nuclear factorkappa B pathway in atherosclerosis: a potential therapeutic target for atherothrombotic vascular disease. Thromb Res 128(2):117123. https://doi.org/10.1016/j.thromres.2011.03.025

121. Gareus R, Kotsaki E, Xanthoulea S, van der Made I, Gijbels MJ, Kardakaris R, Polykratis A, Kollias G, de Winther MP, Pasparakis M (2008) Endothelial cell-specific NF-kappaB inhibition protects mice from atherosclerosis. Cell Metab 8(5):372-383. https://doi.org/10.1016/j.cmet.2008.08.016

122. Zhao M, Liu Y, Wang X, New L, Han J, Brunk UT (2002) Activation of the p38 MAP kinase pathway is required for foam cell formation from macrophages exposed to oxidized LDL. APMIS 110(6):458-468

123. Rahaman SO, Lennon DJ, Febbraio M, Podrez EA, Hazen SL, Silverstein RL (2006) A CD36-dependent signaling cascade is necessary for macrophage foam cell formation. Cell Metab 4(3):211-221. https://doi.org/10.1016/j.cmet.2006.06.007

124. Mercer J, Bennett M (2006) The role of p53 in atherosclerosis. Cell Cycle 5(17):1907-1909. https://doi.org/10.4161/ cc.5.17.3166

125. Yentrapalli R, Azimzadeh O, Barjaktarovic Z, Sarioglu H, Wojcik A, Harms-Ringdahl M, Atkinson MJ, Haghdoost S, Tapio S (2013) Quantitative proteomic analysis reveals induction of premature senescence in human umbilical vein endothelial cells exposed to chronic low-dose rate gamma radiation. Proteomics 13(7):1096-1107. https://doi.org/10.1002/pmic.201200463

126. Halle M, Gabrielsen A, Paulsson-Berne G, Gahm C, Agardh HE, Farnebo F, Tornvall P (2010) Sustained inflammation due to nuclear factor-kappa B activation in irradiated human arteries. J Am Coll Cardiol 55(12):1227-1236. https://doi.org/10.1016/j. jacc.2009.10.047

127. Menezes KM, Wang H, Hada M, Saganti PB (2018) Radiation matters of the heart: a mini review. Front Cardiovasc Med 5:83. https://doi.org/10.3389/fcvm.2018.00083

128. van den Bogaard VA, Ta BD, van der Schaaf A, Bouma AB, Middag AM, Bantema-Joppe EJ, van Dijk LV, van Dijk-Peters FB, Marteijn LA, de Bock GH, Burgerhof JG, Gietema JA, Langendijk JA, Maduro JH, Crijns AP (2017) Validation and modification of a prediction model for acute cardiac events in patients with breast cancer treated with radiotherapy based on three-dimensional dose distributions to cardiac substructures. J Clin Oncol 35(11):1171-1178. https://doi.org/10.1200/ JCO.2016.69.8480

129. Poitevin-Chacon A, Chavez-Nogueda J, Prudencio RR, Fernandez AC, Laguna AR, Linares J, Martinez JC (2018) Dosimetry of the left anterior descending coronary artery in left breast cancer patients treated with postoperative external radiotherapy. Rep Pract Oncol Radiother 23(2):91-96. https://doi.org/10.1016/j. rpor.2018.01.003

130. Darby SC, Cutter DJ, Boerma M, Constine LS, Fajardo LF, Kodama K, Mabuchi K, Marks LB, Mettler FA, Pierce LJ, Trott KR, Yeh ET, Shore RE (2010) Radiation-related heart disease: current knowledge and future prospects. Int J Radiat Oncol Biol Phys 76(3):656-665. https://doi.org/10.1016/j.ijrob p.2009.09.064
131. Darby SC, McGale P, Taylor CW, Peto R (2005) Long-term mortality from heart disease and lung cancer after radiotherapy for early breast cancer: prospective cohort study of about 300,000 women in US SEER cancer registries. Lancet Oncol 6(8):557565. https://doi.org/10.1016/S1470-2045(05)70251-5

132. Soares AR, Martins-Marques T, Ribeiro-Rodrigues T, Ferreira JV, Catarino S, Pinho MJ, Zuzarte M, Isabel Anjo S, Manadas B, J PGS, Pereira P, Girao H, (2015) Gap junctional protein Cx43 is involved in the communication between extracellular vesicles and mammalian cells. Sci Rep 5:13243. https://doi. org/10.1038/srep13243

133. Vinken M (2011) Role of connexin-related signalling in hepatic homeostasis and its relevance for liver-based in vitro modelling. World J Gastrointest Pathophysiol 2(5):82-87. https://doi. org/10.4291/wjgp.v2.i5.82

134. Leybaert L, Lampe PD, Dhein S, Kwak BR, Ferdinandy P, Beyer EC, Laird DW, Naus CC, Green CR, Schulz R (2017) Connexins in cardiovascular and neurovascular health and disease: pharmacological implications. Pharmacol Rev 69(4):396-478. https://doi.org/10.1124/pr.115.012062

135. Wang N, De Vuyst E, Ponsaerts R, Boengler K, Palacios-Prado N, Wauman J, Lai CP, De Bock M, Decrock E, Bol M, Vinken M, Rogiers V, Tavernier J, Evans WH, Naus CC, Bukauskas FF, Sipido KR, Heusch G, Schulz R, Bultynck G, Leybaert L (2013) Selective inhibition of Cx43 hemichannels by Gap19 and its impact on myocardial ischemia/reperfusion injury. Basic Res Cardiol 108(1):309. https://doi.org/10.1007/s0039 5-012-0309-x

136. Yuan D, Sun G, Zhang R, Luo C, Ge M, Luo G, Hei Z (2015a) Connexin 43 expressed in endothelial cells modulates monocyteendothelial adhesion by regulating cell adhesion proteins. Mol Med Rep 12(5):7146-7152. https://doi.org/10.3892/ mmr.2015.4273

137. Retamal MA, Reyes EP, Garcia IE, Pinto B, Martinez AD, Gonzalez C (2015) Diseases associated with leaky hemichannels. Front Cell Neurosci 9:267. https://doi.org/10.3389/fncel .2015.00267

138. Delvaeye T, Vandenabeele P, Bultynck G, Leybaert L, Krysko DV (2018) Therapeutic targeting of connexin channels: new views and challenges. Trends Mol Med 24(12):1036-1053. https ://doi.org/10.1016/j.molmed.2018.10.005

139. Walker DL, Vacha SJ, Kirby ML, Lo CW (2005) Connexin43 deficiency causes dysregulation of coronary vasculogenesis. Dev Biol 284(2):479-498. https://doi.org/10.1016/j.ydbio .2005 .06 .004

140. Clauss SB, Walker DL, Kirby ML, Schimel D, Lo CW (2006) Patterning of coronary arteries in wildtype and connexin 43 knockout mice. Dev Dyn 235(10):2786-2794. https://doi. org/10.1002/dvdy.20887

141. Kirchhoff S, Kim JS, Hagendorff A, Thonnissen E, Kruger O, Lamers WH, Willecke K (2000) Abnormal cardiac conduction and morphogenesis in connexin40 and connexin43 double-deficient mice. Circ Res 87(5):399-405

142. Simon AM, McWhorter AR (2002) Vascular abnormalities in mice lacking the endothelial gap junction proteins connexin37 and connexin40. Dev Biol 251(2):206-220

143. Yamada Y, Izawa H, Ichihara S, Takatsu F, Ishihara H, Hirayama $\mathrm{H}$, Sone T, Tanaka M, Yokota M (2002) Prediction of the risk of myocardial infarction from polymorphisms in candidate genes. $\mathrm{N}$ Engl J Med 347(24):1916-1923. https://doi.org/10.1056/NEJMo a021445

144. Hirashiki A, Yamada Y, Murase Y, Suzuki Y, Kataoka H, Morimoto Y, Tajika T, Murohara T, Yokota M (2003) Association of gene polymorphisms with coronary artery disease in low- or high-risk subjects defined by conventional risk factors. J Am Coll Cardiol 42(8):1429-1437 
145. Boerma M, Forsberg L, Van Zeijl L, Morgenstern R, De Faire U, Lemne C, Erlinge D, Thulin T, Hong Y, Cotgreave IA (1999) A genetic polymorphism in connexin 37 as a prognostic marker for atherosclerotic plaque development. J Intern Med 246(2):211-218

146. Alexander DB, Goldberg GS (2003) Transfer of biologically important molecules between cells through gap junction channels. Curr Med Chem 10(19):2045-2058

147. Herve JC, Derangeon M (2013) Gap-junction-mediated cellto-cell communication. Cell Tissue Res 352(1):21-31. https:// doi.org/10.1007/s00441-012-1485-6

148. de Wit C, Griffith TM (2010) Connexins and gap junctions in the EDHF phenomenon and conducted vasomotor responses. Pflugers Arch 459(6):897-914. https://doi.org/10.1007/s0042 4-010-0830-4

149. De Mello WC (1982) Cell-to-cell communication in heart and other tissues. Prog Biophys Mol Biol 39(3):147-182

150. Hanner F, Sorensen CM, Holstein-Rathlou NH, Peti-Peterdi J (2010) Connexins and the kidney. Am J Physiol Regul Integr Comp Physiol 298(5):R1143-1155. https://doi.org/10.1152/ ajpregu.00808.2009

151. Orellana JA, Diaz E, Schalper KA, Vargas AA, Bennett MV, Saez JC (2011) Cation permeation through connexin 43 hemichannels is cooperative, competitive and saturable with parameters depending on the permeant species. Biochem Biophys Res Commun 409(4):603-609. https://doi.org/10.1016/j. bbrc.2011.05.031

152. Zhao D, Liu R, Li G, Chen M, Shang P, Yang H, Jiang JX, Xu $\mathrm{H}$ (2020) Connexin 43 channels in osteocytes regulate bone responses to mechanical unloading. Front Physiol 11:299. https ://doi.org/10.3389/fphys.2020.00299

153. Riquelme MA, Cardenas ER, Xu H, Jiang JX (2020) The role of connexin channels in the response of mechanical loading and unloading of bone. Int J Mol Sci. https://doi.org/10.3390/ijms2 1031146

154. Meunier C, Wang N, Yi C, Dallerac G, Ezan P, Koulakoff A, Leybaert L, Giaume C (2017) Contribution of astroglial Cx43 hemichannels to the modulation of glutamatergic currents by d-serine in the mouse prefrontal cortex. J Neurosci 37(37):90649075. https://doi.org/10.1523/JNEUROSCI.2204-16.2017

155. Johansen D, Cruciani V, Sundset R, Ytrehus K, Mikalsen SO (2011) Ischemia induces closure of gap junctional channels and opening of hemichannels in heart-derived cells and tissue. Cell Physiol Biochem 28(1):103-114. https://doi.org/10.1159/00033 1719

156. Lu D, Soleymani S, Madakshire R, Insel PA (2012) ATP released from cardiac fibroblasts via connexin hemichannels activates profibrotic P2Y2 receptors. FASEB J 26(6):2580-2591. https:// doi.org/10.1096/fj.12-204677

157. Li F, Sugishita K, Su Z, Ueda I, Barry WH (2001) Activation of connexin-43 hemichannels can elevate $[\mathrm{Ca}(2+)] \mathrm{i}$ and $[\mathrm{Na}(+)]$ $\mathrm{i}$ in rabbit ventricular myocytes during metabolic inhibition. $\mathrm{J}$ Mol Cell Cardiol 33(12):2145-2155. https://doi.org/10.1006/ jmcc.2001.1477

158. Gadicherla AK, Wang N, Bulic M, Agullo-Pascual E, Lissoni A, De Smet M, Delmar M, Bultynck G, Krysko DV, Camara A, Schluter KD, Schulz R, Kwok WM, Leybaert L (2017) Mitochondrial Cx43 hemichannels contribute to mitochondrial calcium entry and cell death in the heart. Basic Res Cardiol 112(3):27. https://doi.org/10.1007/s00395-017-0618-1

159. Delvaeye T, Vandenabeele P, Bultynck G, Leybaert L, Krysko DV (2018) Therapeutic targeting of connexin channels: new views and challenges. Trends Mol Med 24(12):1036-1053. https ://doi.org/10.1016/j.molmed.2018.10.005

160. Ramachandran S, Xie LH, John SA, Subramaniam S, Lal R (2007) A novel role for connexin hemichannel in oxidative stress and smoking-induced cell injury. PLoS ONE 2(8):e712. https:// doi.org/10.1371/journal.pone.0000712

161. Orellana JA, Saez PJ, Shoji KF, Schalper KA, Palacios-Prado N, Velarde V, Giaume C, Bennett MV, Saez JC (2009) Modulation of brain hemichannels and gap junction channels by pro-inflammatory agents and their possible role in neurodegeneration. Antioxid Redox Signal 11(2):369-399. https://doi.org/10.1089/ ars.2008.2130

162. De Vuyst E, Wang N, Decrock E, De Bock M, Vinken M, Van Moorhem M, Lai C, Culot M, Rogiers V, Cecchelli R, Naus CC, Evans WH, Leybaert L (2009) $\mathrm{Ca}(2+)$ regulation of connexin 43 hemichannels in C6 glioma and glial cells. Cell Calcium 46(3):176-187. https://doi.org/10.1016/j.ceca.2009.07.002

163. Wang N, De Bock M, Antoons G, Gadicherla AK, Bol M, Decrock E, Evans WH, Sipido KR, Bukauskas FF, Leybaert L (2012) Connexin mimetic peptides inhibit $\mathrm{Cx} 43$ hemichannel opening triggered by voltage and intracellular $\mathrm{Ca} 2+$ elevation. Basic Res Cardiol 107(6):304. https://doi.org/10.1007/s0039 5-012-0304-2

164. Ramadan R, Vromans E, Anang DC, Decrock E, Mysara M, Monsieurs P, Baatout S, Leybaert L, Aerts A (2019) Single and fractionated ionizing radiation induce alterations in endothelial connexin expression and channel function. Sci Rep 9(1):4643. https://doi.org/10.1038/s41598-019-39317-9

165. Wang N, De Bock M, Decrock E, Bol M, Gadicherla A, Vinken M, Rogiers V, Bukauskas FF, Bultynck G, Leatbaert L (1828) Paracrine signaling through plasma membrane hemichannels. Biochim Biophys Acta 1:35-50. https://doi.org/10.1016/j.bbame m.2012.07.002

166. Decrock E, De Vuyst E, Vinken M, Van Moorhem M, Vranckx K, Wang N, Van Laeken L, De Bock M, D'Herde K, Lai CP, Rogiers V, Evans WH, Naus CC, Leybaert L (2009) Connexin 43 hemichannels contribute to the propagation of apoptotic cell death in a rat C6 glioma cell model. Cell Death Differ 16(1):151163. https://doi.org/10.1038/cdd.2008.138

167. Decrock E, Vinken M, De Vuyst E, Krysko DV, D’Herde K, Vanhaecke T, Vandenabeele P, Rogiers V, Leybaert L (2009) Connexin-related signaling in cell death: to live or let die? Cell Death Differ 16(4):524-536. https://doi.org/10.1038/cdd.2008.196

168. Saez JC, Schalper KA, Retamal MA, Orellana JA, Shoji KF, Bennett MV (2010) Cell membrane permeabilization via connexin hemichannels in living and dying cells. Exp Cell Res 316(15):2377-2389. https://doi.org/10.1016/j.yexcr.2010.05.026

169. De Bock M, Culot M, Wang N, Bol M, Decrock E, De Vuyst E, da Costa A, Dauwe I, Vinken M, Simon AM, Rogiers V, De Ley G, Evans WH, Bultynck G, Dupont G, Cecchelli R, Leybaert L (2011) Connexin channels provide a target to manipulate brain endothelial calcium dynamics and blood-brain barrier permeability. J Cereb Blood Flow Metab 31(9):1942-1957. https://doi. org/10.1038/jcbfm.2011.86

170. Tonkin RS, Bowles C, Perera CJ, Keating BA, Makker PGS, Duffy SS, Lees JG, Tran C, Don AS, Fath T, Liu L, O'Carroll SJ, Nicholson LFB, Green CR, Gorrie C, Moalem-Taylor G (2018) Attenuation of mechanical pain hypersensitivity by treatment with Peptide5, a connexin-43 mimetic peptide, involves inhibition of NLRP3 inflammasome in nerve-injured mice. Exp Neurol 300:1-12. https://doi.org/10.1016/j.expneurol.2017.10.016

171. Mugisho OO, Green CR, Kho DT, Zhang J, Graham ES, Acosta ML (1862) Rupenthal ID (2018) The inflammasome pathway is amplified and perpetuated in an autocrine manner through connexin43 hemichannel mediated ATP release. Biochim Biophys Acta 3:385-393. https://doi.org/10.1016/j.bbagen.2017.11.015

172. Lohman AW, Billaud M, Isakson BE (2012) Mechanisms of ATP release and signalling in the blood vessel wall. Cardiovasc Res 95(3):269-280. https://doi.org/10.1093/cvr/cvs187 
173. Retamal MA, Froger N, Palacios-Prado N, Ezan P, Saez PJ, Saez JC, Giaume C (2007) Cx43 hemichannels and gap junction channels in astrocytes are regulated oppositely by proinflammatory cytokines released from activated microglia. J Neurosci 27(50):13781-13792. https://doi.org/10.1523/JNEUR OSCI.2042-07.2007

174. Cronin M, Anderson PN, Cook JE, Green CR, Becker DL (2008) Blocking connexin43 expression reduces inflammation and improves functional recovery after spinal cord injury. Mol Cell Neurosci 39(2):152-160. https://doi.org/10.1016/j. men.2008.06.005

175. Danesh-Meyer HV, Huang R, Nicholson LF, Green CR (2008) Connexin43 antisense oligodeoxynucleotide treatment downregulates the inflammatory response in an in vitro interphase organotypic culture model of optic nerve ischaemia. J Clin Neurosci 15(11):1253-1263. https://doi.org/10.1016/j. jocn.2008.08.002

176. Mori R, Power KT, Wang CM, Martin P, Becker DL (2006) Acute downregulation of connexin 43 at wound sites leads to a reduced inflammatory response, enhanced keratinocyte proliferation and wound fibroblast migration. J Cell Sci 119(Pt 24):51935203. https://doi.org/10.1242/jcs.03320

177. Tsuchida S, Arai Y, Kishida T, Takahashi KA, Honjo K, Terauchi R, Inoue H, Oda R, Mazda O, Kubo T (2013) Silencing the expression of connexin 43 decreases inflammation and joint destruction in experimental arthritis. J Orthop Res 31(4):525530. https://doi.org/10.1002/jor.22263

178. Tarzemany R, Jiang G, Jiang JX, Larjava H, Hakkinen L (2017) Connexin 43 hemichannels regulate the expression of wound healing-associated genes in human gingival fibroblasts. Sci Rep 7(1):14157. https://doi.org/10.1038/s41598-017-12672-1

179. Willebrords J, Cogliati B, Pereira IVA, da Silva TC, Crespo Yanguas S, Maes M, Govoni VM, Lima A, Felisbino DA, Decrock E, Nogueira MS, de Castro IA, Leclercq I, Leybaert L, Rodrigues RM, Vinken M (2017) Inhibition of connexin hemichannels alleviates non-alcoholic steatohepatitis in mice. Sci Rep 7(1):8268. https://doi.org/10.1038/s41598-017-08583-w

180. Lillo MA, Himelman E, Shirokova N, Xie LH, Fraidenraich D, Contreras JE (2019) S-nitrosylation of connexin43 hemichannels elicits cardiac stress-induced arrhythmias in Duchenne muscular dystrophy mice. JCI Insight. https://doi.org/10.1172/jci.insight.130091

181. Himelman E, Lillo MA, Nouet J, Gonzalez JP, Zhao Q, Xie LH, Li H, Liu T, Wehrens XH, Lampe PD, Fishman GI, Shirokova N, Contreras JE, Fraidenraich D (2020) Prevention of connexin-43 remodeling protects against Duchenne muscular dystrophy cardiomyopathy. J Clin Invest 130(4):1713-1727. https://doi. org/10.1172/JCI128190

182. Ghazizadeh Z, Kiviniemi T, Olafsson S, Plotnick D, Beerens ME, Zhang K, Gillon L, Steinbaugh MJ, Barrera V, Sui SH, Werdich AA, Kapur S, Eranti A, Gunn J, Jalkanen J, Airaksinen J, Kleber AG, Hollmen M, MacRae CA (2020) Metastable atrial state underlies the primary genetic substrate for MYL4 mutationassociated atrial fibrillation. Circulation 141(4):301-312. https ://doi.org/10.1161/CIRCULATIONAHA.119.044268

183. Gonzalez JP, Ramachandran J, Xie LH, Contreras JE, Fraidenraich D (2015) Selective connexin43 inhibition prevents isoproterenol-induced arrhythmias and lethality in muscular dystrophy mice. Sci Rep 5:13490. https://doi.org/10.1038/srep13490

184. Kim JC, Perez-Hernandez M, Alvarado FJ, Maurya SR, Montnach J, Yin Y, Zhang M, Lin X, Vasquez C, Heguy A, Liang FX, Woo SH, Morley GE, Rothenberg E, Lundby A, Valdivia HH, Cerrone M, Delmar M (2019) Disruption of $\mathrm{Ca}(2+) \mathrm{i}$ homeostasis and connexin 43 hemichannel function in the right ventricle precedes overt arrhythmogenic cardiomyopathy in plakophilin-2-deficient mice. Circulation 140(12):1015-1030. https://doi.org/10.1161/CIRCULATIONAHA.119.039710
185. Maatouk L, Yi C, Carrillo-de Sauvage MA, Compagnion AC, Hunot S, Ezan P, Hirsch EC, Koulakoff A, Pfrieger FW, Tronche F, Leybaert L, Giaume C, Vyas S (2018) Glucocorticoid receptor in astrocytes regulates midbrain dopamine neurodegeneration through connexin hemichannel activity. Cell Death Differ. https ://doi.org/10.1038/s41418-018-0150-3

186. Freitas-Andrade M, Wang N, Bechberger JF, De Bock M, Lampe PD, Leybaert L, Naus CC (2019) Targeting MAPK phosphorylation of Connexin 43 provides neuroprotection in stroke. J Exp Med 216(4):916-935. https://doi.org/10.1084/jem.20171452

187. Walrave L, Pierre A, Albertini G, Aourz N, De Bundel D, Van Eeckhaut A, Vinken M, Giaume C, Leybaert L, Smolders I (2018) Inhibition of astroglial connexin43 hemichannels with TAT-Gap19 exerts anticonvulsant effects in rodents. Glia. https ://doi.org/10.1002/glia.23341

188. Oshima A (2014) Structure and closure of connexin gap junction channels. FEBS Lett 588(8):1230-1237. https://doi. org/10.1016/j.febslet.2014.01.042

189. Morel S (2014) Multiple roles of connexins in atherosclerosis- and restenosis-induced vascular remodelling. J Vasc Res 51(2):149-161. https://doi.org/10.1159/000362122

190. Kwak BR, Mulhaupt F, Veillard N, Gros DB, Mach F (2002) Altered pattern of vascular connexin expression in atherosclerotic plaques. Arterioscler Thromb Vasc Biol 22(2):225-230

191. Kwak BR, Silacci P, Stergiopulos N, Hayoz D, Meda P (2005) Shear stress and cyclic circumferential stretch, but not pressure, alter connexin 43 expression in endothelial cells. Cell Commun Adhes 12(5-6):261-270. https://doi.org/10.1080/15419060500514119

192. Feaver RE, Hastings NE, Pryor A, Blackman BR (2008) GRP78 upregulation by atheroprone shear stress via p38-, alpha2beta1dependent mechanism in endothelial cells. Arterioscler Thromb Vasc Biol 28(8):1534-1541. https://doi.org/10.1161/ATVBA HA.108.167999

193. DePaola N, Davies PF, Pritchard WF Jr, Florez L, Harbeck N, Polacek DC (1999) Spatial and temporal regulation of gap junction connexin43 in vascular endothelial cells exposed to controlled disturbed flows in vitro. Proc Natl Acad Sci USA 96(6):3154-3159

194. Gabriels JE, Paul DL (1998) Connexin43 is highly localized to sites of disturbed flow in rat aortic endothelium but connexin 37 and connexin 40 are more uniformly distributed. Circ Res 83(6):636-643

195. Heo KS, Fujiwara K, Abe J (2014) Shear stress and atherosclerosis. Mol Cells 37(6):435-440. https://doi.org/10.14348/molce 1ls.2014.0078

196. Blackburn JP, Peters NS, Yeh H-I, Rothery S, Green CR, Severs NJ (1995) Upregulation of connexin43 gap junctions during early stages of human coronary atherosclerosis. Arterioscler Thromb Vasc Biol 15(8):1219-1228. https://doi.org/10.1161/01. Atv.15.8.1219

197. Yuan D, Sun G, Zhang R, Luo C, Ge M, Luo G, Hei Z (2015b) Connexin 43 expressed in endothelial cells modulates monocyte-endothelial adhesion by regulating cell adhesion proteins. Mol Med Rep 12(5):7146-7152. https://doi.org/10.3892/ mmr.2015.4273

198. Kwak BR, Veillard N, Pelli G, Mulhaupt F, James RW, Chanson M, Mach F (2003) Reduced connexin43 expression inhibits atherosclerotic lesion formation in low-density lipoprotein receptordeficient mice. Circulation 107(7):1033-1039

199. Wong CW, Burger F, Pelli G, Mach F, Kwak BR (2003) Dual benefit of reduced $\mathrm{Cx} 43$ on atherosclerosis in LDL receptordeficient mice. Cell Commun Adhes 10(4-6):395-400

200. Saez JC, Contreras-Duarte S, Gomez GI, Labra VC, Santibanez CA, Gajardo-Gomez R, Avendano BC, Diaz EF, Montero TD, Velarde V, Orellana JA (2018) Connexin 43 hemichannel activity promoted by pro-inflammatory cytokines and high glucose 
alters endothelial cell function. Front Immunol 9:1899. https:// doi.org/10.3389/fimmu.2018.01899

201. Stachon P, Geis S, Peikert A, Heidenreich A, Michel NA, Unal F, Hoppe N, Dufner B, Schulte L, Marchini T, Cicko S, Ayata K, Zech A, Wolf D, Hilgendorf I, Willecke F, Reinohl J, von Zur MC, Bode C, Idzko M, Zirlik A (2016) Extracellular ATP induces vascular inflammation and atherosclerosis via purinergic receptor Y2 in mice. Arterioscler Thromb Vasc Biol 36(8):1577-1586. https ://doi.org/10.1161/ATVBAHA.115.307397

202. Pfenniger A, Chanson M, Kwak BR (2013) Connexins in atherosclerosis. Biochim Biophys Acta 1828(1):157-166. https://doi. org/10.1016/j.bbamem.2012.05.011

203. Yeh HI, Lu CS, Wu YJ, Chen CC, Hong RC, Ko YS, Shiao MS, Severs NJ, Tsai CH (2003) Reduced expression of endothelial connexin37 and connexin40 in hyperlipidemic mice: recovery of connexin 37 after 7-day simvastatin treatment. Arterioscler Thromb Vasc Biol 23(8):13911397. https://doi.org/10.1161/01.ATV.0000083508.21989.15

204. Alonso F, Boittin FX, Beny JL, Haefliger JA (2010) Loss of connexin40 is associated with decreased endothelium-dependent relaxations and eNOS levels in the mouse aorta. Am J Physiol Heart Circ Physiol 299(5):H1365-1373. https://doi.org/10.1152/ajphe art.00029.2010

205. Napoli C, de Nigris F, Williams-Ignarro S, Pignalosa O, Sica V, Ignarro LJ (2006) Nitric oxide and atherosclerosis: an update. Nitric Oxide 15(4):265-279. https://doi.org/10.1016/j.niox.2006.03.011

206. Wong CW, Christen T, Roth I, Chadjichristos CE, Derouette JP, Foglia BF, Chanson M, Goodenough DA, Kwak BR (2006) Connexin37 protects against atherosclerosis by regulating monocyte adhesion. Nat Med 12(8):950-954. https://doi.org/10.1038/nm1441

207. Pfenniger A, Wong C, Sutter E, Cuhlmann S, Dunoyer-Geindre S, Mach F, Horrevoets AJ, Evans PC, Krams R, Kwak BR (2012) Shear stress modulates the expression of the atheroprotective protein Cx37 in endothelial cells. J Mol Cell Cardiol 53(2):299-309. https://doi.org/10.1016/j.yjmcc.2012.05.011

208. Liu Y, Fu YQ, Peng WJ, Yu YR, Wu YS, Yan H, Huang QR, He M, Luo D (2016) Rutaecarpine reverses the altered connexin expression pattern induced by oxidized low-density lipoprotein in monocytes. J Cardiovasc Pharmacol 67(6):519-525. https://doi. org/10.1097/FJC.0000000000000372

209. Chadjichristos CE, Scheckenbach KE, van Veen TA, Richani Sarieddine MZ, de Wit C, Yang Z, Roth I, Bacchetta M, Viswambharan H, Foglia B, Dudez T, van Kempen MJ, Coenjaerts FE, Miquerol L, Deutsch U, Jongsma HJ, Chanson M, Kwak BR (2010) Endothelial-specific deletion of connexin 40 promotes atherosclerosis by increasing CD73-dependent leukocyte adhesion. Circulation 121(1):123-131. https://doi.org/10.1161/CIRCULATIO NAHA.109.867176

210. Denis JF, Scheckenbach KEL, Pfenniger A, Meens MJ, Krams R, Miquerol L, Taffet S, Chanson M, Delmar M, Kwak BR (2017) Connexin 40 controls endothelial activation by dampening NFkappaB activation. Oncotarget 8(31):50972-50986. https://doi. org/10.18632/oncotarget. 16438

211. Larson DM, Christensen TG, Sagar GD, Beyer EC (2001) TGFbeta1 induces an accumulation of connexin 43 in a lysosomal compartment in endothelial cells. Endothelium 8(4):255-260

212. Eugenin EA, Branes MC, Berman JW, Saez JC (2003) TNF-alpha plus IFN-gamma induce connexin 43 expression and formation of gap junctions between human monocytes/macrophages that enhance physiological responses. J Immunol 170(3):1320-1328

213. van Rijen HV, van Kempen MJ, Postma S, Jongsma HJ (1998) Tumour necrosis factor alpha alters the expression of connexin 43 , connexin40, and connexin 37 in human umbilical vein endothelial cells. Cytokine 10(4):258-264. https://doi.org/10.1006/ cyto.1997.0287

214. Edwards GO, Botchway SW, Hirst G, Wharton CW, Chipman JK, Meldrum RA (2004) Gap junction communication dynamics and bystander effects from ultrasoft X-rays. Br J Cancer 90(7):1450 1456. https://doi.org/10.1038/sj.bjc.6601686

215. Ghosh S, Kumar A, Tripathi RP, Chandna S (2014) Connexin-43 regulates p38-mediated cell migration and invasion induced selectively in tumour cells by low doses of gamma-radiation in an ERK1/2-independent manner. Carcinogenesis 35(2):383-395. https:// doi.org/10.1093/carcin/bgt303

216. Glover D, Little JB, Lavin MF, Gueven N (2003) Low dose ionizing radiation-induced activation of connexin 43 expression. Int J Radiat Biol 79(12):955-964. https://doi.org/10.1080/09553000310001632895

217. Kasper M, Traub O, Reimann T, Bjermer L, Grossmann H, Muller M, Wenzel KW (1996) Upregulation of gap junction protein connexin43 in alveolar epithelial cells of rats with radiation-induced pulmonary fibrosis. Histochem Cell Biol 106(4):419-424

218. Nielsen MS, Axelsen LN, Sorgen PL, Verma V, Delmar M, Holstein-Rathlou NH (2012) Gap junctions. Compr Physiol 2(3):19812035. https://doi.org/10.1002/cphy.c110051

219. Azzam EI, de Toledo SM, Little JB (2003) Expression of CONNEXIN43 is highly sensitive to ionizing radiation and other environmental stresses. Cancer Res 63(21):7128-7135

220. Amino M, Yoshioka K, Fujibayashi D, Hashida T, Furusawa Y, Zareba W, Ikari Y, Tanaka E, Mori H, Inokuchi S, Kodama I, Tanabe T (2010) Year-long upregulation of connexin43 in rabbit hearts by heavy ion irradiation. Am J Physiol Heart Circ Physiol 298(3):H1014-1021. https://doi.org/10.1152/ajpheart.00160.2009

221. Amino M, Yoshioka K, Furusawa Y, Tanaka S, Kawabe N, Hashida T, Tsukada T, Izumi M, Inokuchi S, Tanabe T, Ikari Y (2017) Inducibility of ventricular arrhythmia 1 year following treatment with heavy ion irradiation in dogs with myocardial infarction. Pacing Clin Electrophysiol 40(4):379-390. https://doi.org/10.1111/pace.13031

222. Amino M, Yoshioka K, Tanabe T, Tanaka E, Mori H, Furusawa Y, Zareba W, Yamazaki M, Nakagawa H, Honjo H, Yasui K, Kamiya K, Kodama I (2006) Heavy ion radiation up-regulates Cx43 and ameliorates arrhythmogenic substrates in hearts after myocardial infarction. Cardiovasc Res 72(3):412-421. https://doi. org/10.1016/j.cardiores.2006.09.010

223. Liu K, Kasper M, Bierhaus A, Langer S, Muller M, Trott KR (1997) Connexin 43 expression in normal and irradiated mouse skin. Radiat Res 147(4):437-441

224. Banaz-Yasar F, Tischka R, Iliakis G, Winterhager E, Gellhaus A (2005) Cell line specific modulation of connexin 43 expression after exposure to ionizing radiation. Cell Commun Adhes 12(5-6):249259. https://doi.org/10.1080/15419060500514101

225. Autsavapromporn N, de Toledo SM, Little JB, Jay-Gerin JP, Harris AL, Azzam EI (2011) The role of gap junction communication and oxidative stress in the propagation of toxic effects among highdose $\alpha$-particle-irradiated human cells. Radiat Res 175(3):347-357. https://doi.org/10.1667/RR2372.1

226. Autsavapromporn N, Plante I, Liu C, Konishi T, Usami N, Funayama T, Azzam EI, Murakami T, Suzuki M (2015) Genetic changes in progeny of bystander human fibroblasts after microbeam irradiation with $\mathrm{X}$-rays, protons or carbon ions: the relevance to cancer risk. Int J Radiat Biol 91(1):62-70. https://doi.org/10.3109/09553002.2014.950715

227. Bishayee A, Hill HZ, Stein D, Rao DV, Howell RW (2001) Free radical-initiated and gap junction-mediated bystander effect due to nonuniform distribution of incorporated radioactivity in a threedimensional tissue culture model. Radiat Res 155(2):335-344

228. Ramadan R, Vromans E, Anang DC, Goetschalckx I, Hoorelbeke D, Decrock E, Baatout S, Leybaert L, Aerts A (2020) Connexin43 hemichannel targeting with TAT-Gap19 alleviates radiationinduced endothelial cell damage. Front Pharmacol 11:212. https ://doi.org/10.3389/fphar.2020.00212

Publisher's Note Springer Nature remains neutral with regard to jurisdictional claims in published maps and institutional affiliations. 